\title{
ESTUDO DA VARIABILIDADE DE PRODUÇÃO DE AFLATOXINAS POR LINHAGENS DE Aspergillus flaous EM DIFERENTES TEMPOS DE ESTOCAGEM
}

\author{
MARTA HIROMI TANIWAKI
}

Orientador: HOMERO FONSECA

Dissertação apresentada à Escola Superior de Agricultura "Luiz de Queiroz", da Universidade de São Paulo, para obtenção do título de Mestre em Agronomia - Área de Concentração: - Microbiologia Agrícola.

$P|R A C| C A B A$

Estado de São Paulo - Brasil

Novembro, 1984 
"Tudo fez Deus formoso no Seu devido tempo, também pôs a eternidade no coração do homem, sem que este possa descobrir as obras que Deus fez desde o princípio até o fim". 
Aos meus pais,

que sempre me incentivaram, $e$ em todas as horas me apoiaram 


\section{AGRADECIMENTOS}

Muitos colaboraram na realização deste trabalho, e quero nesta hora agradecer a todos que de alguma forma contribuíram, e também me dirigir especialmente para:

Ao Prof. Dr. Homero Fonseca, pela valiosa orientação na ela boração deste trabalho, bem como pelo carinho e incentivo em todas as horas.

A Profa. Dra. Aline Aparecida Pizzirani Kleiner, pelo apoio e pela orientação na parte de citologia.

A Dra. Maria Luiza Filgueiras Barbosa, pelo incentivo nos trabalhos iniciais.

Ao ITAL - Instituto de Tecnologia de Alimentos, especialmente à Dra. Maria Regina Sartori, chefe da Seção de Armazenamento e Beneficiamento, pelás facilidades concedidas.

A Coordenadoria de Aperfeiçoamento de Pessoal de Nível Superior (CAPES) pela bolsa concedida.

Ao Prof. Dr. Urgel de Almeida Lima pelas facilidades concedidas, como chefe do Departamento de Tecnologia Rural, e também ao Prof. Dr. Alcides Martinelli filho e Prof. Dr. Rodolfo Camargo, pela colaboração na parte de microbiologia. 
Aos Amigos Anne Lore Schnoeder, Luiz Eduardo Baldijão, Maria Amélia Toffolo Rodini, Maria Aparecida Grecchi e Si las César silva, pela amizade e incentivo.

A Sandra Cecillia Miano, Ivani Valarini e João Baptista Be raldo, pelo auxîlio técnico e colaboração.

A Dora Regina Duarte Chiaramonte, pelo auxílio prestado na confecção dos grāficos.

Aos Irmãos Noemi Nosomi Taniwaki e Paulo Taniwaki, pelo carinho e apoio. 
INDICE

Página

LISTA DE TABELAS viii

LISTA DE FIGURAS $\ldots \ldots \ldots \ldots \ldots \ldots \ldots \ldots \ldots \ldots \ldots \ldots \ldots \ldots \ldots \ldots$

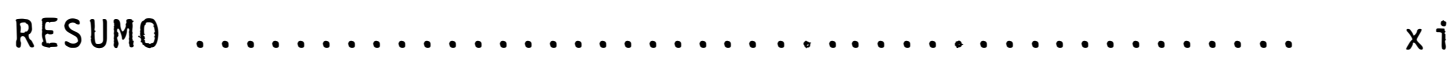

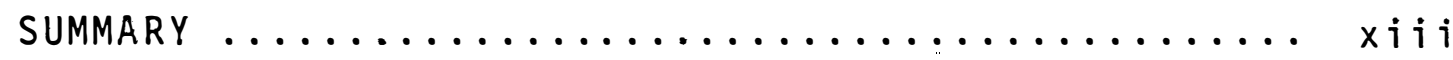

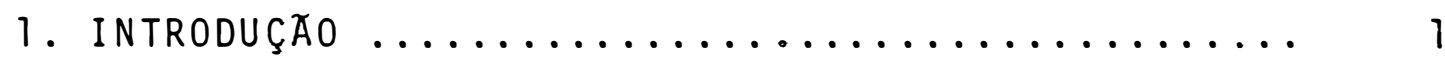

2. REVISÁO DE Literatura $\ldots \ldots \ldots \ldots \ldots \ldots \ldots \ldots \ldots$

2.1. Aspectos Gerais .................. 4

2.2. Estudos Fisiológicos ................ 8

2.3. Estudos Genéticos ................... 11

2.4. Estudos Bioquimicos ................ 15

2.5. Estudos Morfológicos e Citológicos ........ 17

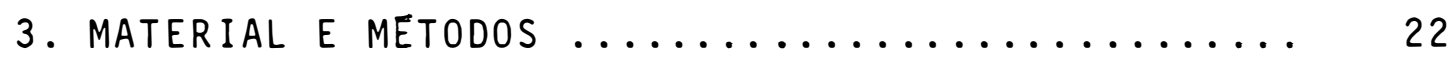

3.1. Organismo Produtor de Aflatoxinas ....... 22

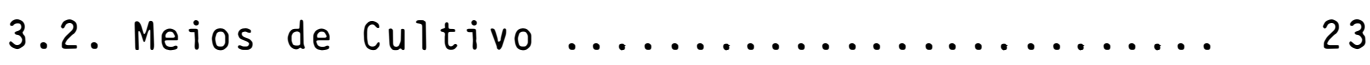

3.2.1. Meio de Czapeck, citado por RAPER e FENNELL (1965) .......... 24

3.2.2. Meio de Czapeck modificado por FONSECA et alii (1974) ........ 24

3.3. Meio de Cultura para Produção de

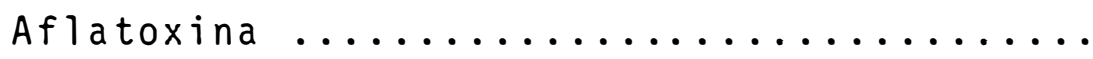
25

3.3.1. Meio "YES", descrito por DAVIS et alii (1966) ........... 25

3.4. Métodos para Conservação de Fungos ....... 25 3.4.1. Método de transferēncia periōdica ....................... 25

3.4.2. Método de preservação em

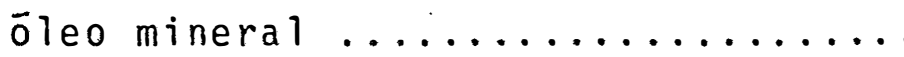


3.5. Extração das Aflatoxinas ............. 26

3.5.1. Extração do meio de cultura ....... 26

3.5.2. Extração do micélio ............ 27

3.6. Determinação Quantitativa das Afla-

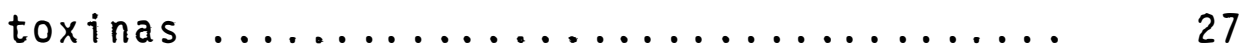

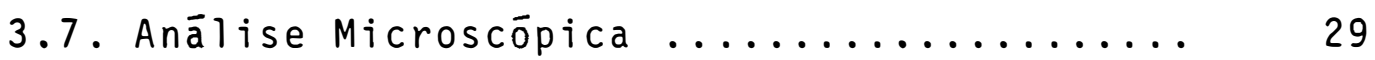

3.7.1. Corante safranina - 0,10\% ....... 29

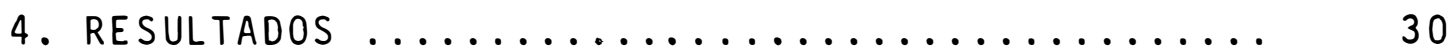

4.1. Produção Inicial de Aflatoxinas ......... 30

4.2. Produção de Aflatoxinas pelas Linha-

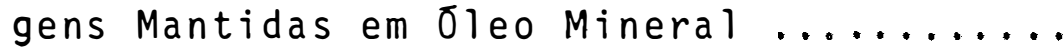

4.3. Produção de Aflatoxinas pelas Linhagens Repicadas Periodicamente ...........

4.4. Observação dos Caracteres Morfológi-

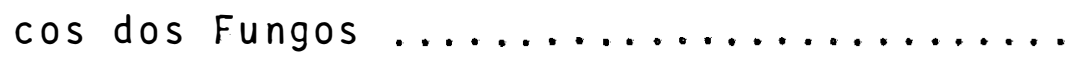

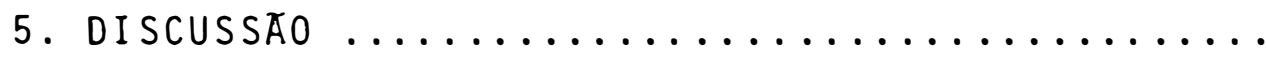

5.1. Variação na Produção de Aflatoxinas nas Linhagens Mantidas em oleo Mineral e Repicadas Periodicamente ...........

5.2. Perda na Capacidade de Produzir Afla

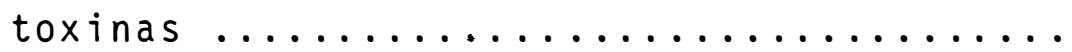

5.3. Observação dos Caracteres Morfológi-

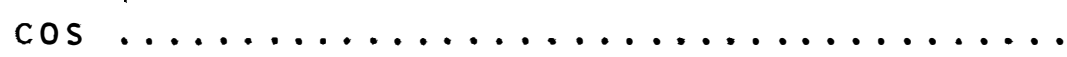

5.4. Produção de Aflatoxinas em Substratos Diferentes ..................... 54

5.5. Aflatoxinas e Micovirus ............... 57

5.6. Aflatoxinas: um Metabólito Secundārio .... 58

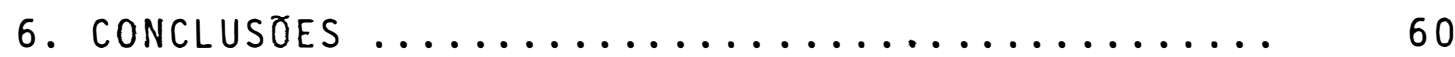

LITERATURA CITADA .................... 62 


\section{LISTA DE TABELAS}

Tabela no

Página

1 Produção de aflatoxinas $B_{1}$ e $G_{1}$ no meio de cultura e no micélio por linhagens de A. Glauus isoladas por FONSECA et

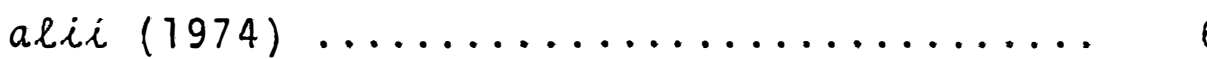

2 Produção de aflatoxinas $B_{1}$ e $G_{1}$ no meio de cultura e no micélio por linhagens de A. blavus isoladas por FONSECA et alii (1974) após 9 anos de estocagem ......

3 Produção inicial de aflatoxinas das 1 inhagens do grupo A. Glavus, isoladas do amendoim (Média de duas repetições) .......

4 Produção de aflatoxinas da linhagem 2, mantida em óleo mineral (Média de duas repetições) $\ldots . \ldots \ldots \ldots \ldots \ldots \ldots \ldots \ldots \ldots$

5 Produção de aflatoxinas da linhagem 4, mantida em óleo mineral (Média de duas repetições)

6 Produção de aflatoxinas da linhagem 6 , mantida em óleo mineral (Média de duas

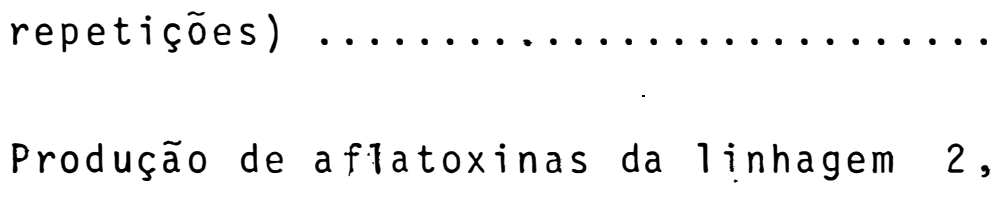
repicada periodicamente (Média de duas

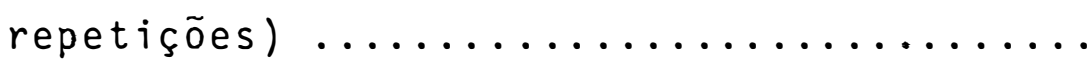


Tabela no

Pāgina

8 Produção de aflatoxinas da linhagem 4, repicada periodicamente (Média de duas repetições) $\ldots \ldots \ldots \ldots \ldots \ldots \ldots \ldots \ldots \ldots \ldots$

9 Produção de aflatoxinas da linhagem 6 , repicada periodicamente (Média de duas

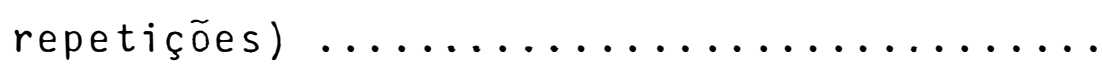




\section{LISTA DE FIGURAS}

Figura no

Pāgina

1 Produção de aflatoxinas $B_{1}$ e $G_{1}$ (ppm)

no meio de cultura e no micélio, da

linhagem 2 , mantida em óleo mineral ..... 36

2 Produção de aflatoxinas $B_{1}$ e $G_{1}$ (ppm)

no meio de cultura e no micélio, da

linhagem 4 , mantida em óleo mineral .......

3 Produção de aflatoxinas $B_{1}$ e $G_{1}$ (ppm)

no meio de cultura e no micélio, da

linhagem 6 , mantida em 0 leo mineral .......

4 Produção de aflatoxinas $B_{1}$ e $G_{1}$ (ppm)

no meio de cultura e no micélio, da

1 inhagem 2 , repicada periodicamente .......

5 Produção de aflatoxinas $B_{1}$ e $G_{1}$ (ppm)

no meio de cultura e no micélio, da

linhagem 4 , repicada periodicamente ...... 44

6 Produção de aflatoxinas $B_{1}$ e $G_{1}$ (ppm)

no meio de cultura e no micélio, da

linhagem 6 , repicada periodicamente ....... 


\title{
ESTUDO DA VARIABILIDADE DE PRODUÇAOO DE AFLATOXINAS POR LINHAGENS DE ASPERGILLUS FLAVUS EM DIFERENTES TEMPOS DE ESTOCAGEM
}

\author{
Marta Hiromi Taniwaki \\ Orientador: Homero Fonseca
}

RESUMO

0 presente trabalho foi realizado, com a finalidade de estudar a produção de aflatoxinas, por linhagens de A. Glauus, recém isoladas, em diferentes tempos de estocagem, a fim de contribuir para um melhor entendimento do mecanismo de variação na produção de aflatoxinas. Para isso, foram utilizadas trēs 1 inhagens de A. Glavus produtoras de aflatoxinas, classificadas como: A) grande produtora; B) média produtora e C) baixa produtora.

Neste experimento, que durou 280 dias, os fungos foram estudados em dois métodos de preservação: mantido em óleo mineral, no meio de Czapeck, e repicado periodicamente no meio de Czapeck modificado. A anālise de produção de aflatoxina foi efetuada de 30 em 30 dias, seguindo a técnica de extração com clorofórmio (meio de cultura) e ácetona $70 \%$ (micélio). A quantificação da toxina foi feita 
por cromatografia em camada delgada pela técnica de avaliação visual.

Foi constatada uma variação na produção de toxina em todas as linhagens, contudo elas não perderam suas características de grande, média e baixa produtora. Até o momento nenhuma linhagem perdeu sua capacidade de sin tetizar aflatoxinas.

observações microscópicas revelaram zonas de espessamento e alargamento de hifas, além de algumas estruturas globosas que podem estar relacionadas às āreas de produção de aflatoxinas. 


\section{STUDY OF THE VARIABILITY IN THE PRODUCTION OF AFLATOXINS BY ASPERGILLUS FLAVUS STRAINS AFTER DIFFERENT STORAGE TIMES}

Marta Hiromi Taniwaki Adviser: Homero Fonseca

\section{SUMMARY}

The present work was carried out aiming to study the aflatoxin production, by strains of Aspergillus flavus, recently isolated, after different storage times, in order to better understand the mechanisms of possible variations in the aflatoxin production. To cope with this objective, three A. Glavus aflatoxin producing strains were utilized, classified as: a) high producer; b) medium producer and c) low producer.

The experiment lasted 280 days and the molds were studied in two preservation methods: oil covered slants on Czapeck's medium and periodic transfer on Gzapeck's modified medium. The quantification of the aflatoxin produced was made at 30 days intervals. The mycelium was extracted with $70 \%$ acetone and then transfered to chloroform and culture medium with chloroform followed by thin-layer chromatography and visual determination by technique of 
dilution-to-extintion.

The production of aflatoxins by all strains varied but they did not lose their characteristics of high, medium and low producers. Till now the strains did not lose their capacity to syntetize aflatoxin.

Microscopic examinations revealed thickned zones and hifal enlargements over some globoses structures that can be related with aflatoxin production sites. 


\section{INTRODUÇAO}

Em 1960, a morte de mais de cem mil peruzinhos na Inglaterra, alimentados com ração contaminada por aflatoxinas produzidas pelo fungo Aspergillus blavus, despertou a atenção dos pesquisadores para o problema das micotoxinas.

Aflatoxinas são metabólitos secundārios do A. Glavus, responsāveis por intoxicações e têm se mostrado cancerígenas a diversas espécies de animais. Devido a essa característica, o estudo das aflatoxinas tem sido alvo de atenção nunca devotadas a nenhum outro problema relacionado a fungos (CHRISTENSEN, 1975). Uma série de aflatoxinas são produzidas por A. Glavus e linhagens relacionadas, destacan do-se $B_{1}$ e $B_{2}, G_{1}$ e $G_{2}$, que se apresentam com fluorescência azul violeta e esverdeada, respectivamente, quando analisadas em cromatografia de camada delgada à luz ultravioleta em $365 \mathrm{~nm}$ e estão entre as micotoxinas mais potentes. 
Qualquer produto vegetal ou animal é susceptível ao ataque por fungos, desde que as condições ambientais e do substrato sejam propicias e, portanto, qualquer daqueles produtos pode representar fonte potencial de micotoxinas.

Atualmente já se sabe que existem linhagens de A. Glavus que não produzem aflatoxinas, outras que só produzem as do grupo B e outras só do grupo $G$.

Inūmeras pesquisas têm demonstrado que hā considerāvel variação na capacidade para produzir aflatoxinas pelas diversas linhagens de A. Glavus e A.parasiticus, mesmo quando são isoladas da mesma fonte (LEAICH e PAPA, 1974). Um dos maiores problemas encontrados pelos pesquisadores no estudo de produção de aflatoxinas é a variação no nível de produção que uma deterninada linhagem apresenta durante todo o experimento. Uma linhagem pode ser altamente toxigẽnica e posteriormente perder esta alta toxigenicidade, não se sabendo se esta perda foi devida a fatores externos, como as condições e tempo de estocagem, ou, se há outros fatores envolvidos (FONSECA) I/.

Desta forma, o presente trabalho visa estudar principalmente a influēncia do tempo na produção de

I/ FONSECA, H. 1980. Comunicação pessoal. 
aflatoxinas por linhagens de $A$. Glavus em diferentes tempos de estocagem, a fim de contribuir para melhor entendimento do mecanismo de variação na produção de aflatoxinas. Portanto é objetivo do trabalho:

- Determinar quantitativamente a produção de aflatoxinas pelo A. Glavus, após a estocagem por diferentes períodos de tempo (repetibilidade de produção de aflatoxinas).

- Analisar caracteres morfológicos e citológicos, nas linhagens estudadas, para relacionar com o mecanismo de produção de aflatoxinas nestas linhagens. 


\section{REVISAOO DE LITERATURA}

Estudos fisiológicos, genéticos, bioquímicos e citológicos, em Aspergillus blavus e Aspergillus parasiticus, tēm sido realizados, juntamente ou não, com o carāter produção de aflatoxina.

\subsection{Aspectos Gerais}

Aflatoxinas são sintetizadas por duas espécies intimamente relacionadas, A. Glavus e A. parasiticus, com base em RAPER e FENNELL (1965). Estas espécies são mui to semelhantes entre si, e as diferenças, na maior parte, são baseadas na textura e coloração das colōnias, fiālides uni ou biseriadas e tamanho do conídio (MIROCHA et alii, 1979). De acordo com LIN (1980), vārios gẽneros e espécies de fungos jā foram relatados como produtores de aflatoxinas, porém, a maioria destes relatos ainda precisam de confirmação. Atualmente, pode-se dizer que os fungos grande 
produtores de aflatoxinas pertencem a estas duas espécies, A. Glavus e A. parasiticus, ambas pertencentes ao grupo-espécie A. blavus (RAPER e FENNELL, 1965).

0 fungo A. blavus foi descrito por RAPER e FENNELL (1965) como sendo um fungo filamentoso, com abundante conidiação, quando crescido em meio de Czapeck sōlido. Seu crescimento é rápido, plano e radiado, sua cor ama relo-esverdeado tende a verde oliva, após longo período de desenvolvimento.

Alguns fungos produzem toxinas, enquanto outros não. Além disso, nem todas as linhagens de espécies toxigēnicas produzem toxinas. Conforme SCHROEDER e CARLTON (1973), linhagens de espécies produtoras de aflatoxinas do grupo A. flavus, variam grandemente na habilidade de produzir e acumular compostos das séries de aflatoxinas.

LIN (1980) revisando vários autores, observou que embora todas as linhagens de A. parasiticus sejam produtoras de aflatoxinas, nem todas as linhagens de A. Kla vus são capazes de produzir. Além disso, A. parasiticus é geralmente maior produtor de aflatoxina do que $A$. blavus $e$ parece que todas as linhagens de A. parasiticus conhecidas são produtoras das quatro aflatoxinas $\left(B_{1}, B_{2}, G_{1}\right.$ e $\left.G_{2}\right)$, e $\underline{n}$ quanto as linhagens produtoras de A. Glavus na maioria das 
vezes produzem somente duas aflatoxinas ( $B_{1}$ e $\left.B_{2}\right)$.

FONSECA et alie (1974) isolaram algumas

Iinhagens de A. Glavus, as quais produziam aflatoxinas em grandes quantidades, tanto no meio de cultura, como no. micétio (Tabela 1).

Estes fungos foram guardados na Micoteca do Departamento de Tecnologia Rural da ESALQ, pelo método de conservação em óleo mineral.

Tabela 1. Produção de aflatoxinas $B_{1}$ e $G_{1}$ no meio de cultú ra e no micélio por linhagens de $A$. flavus isoladas por FONSECA et alii (1974)

\begin{tabular}{lccccc}
\hline Linhagem & \multicolumn{2}{c}{ Produção de aflatoxinas (ppm) } \\
& $\begin{array}{c}\text { Me io de cultura } \\
B_{1}\end{array}$ & $G_{1}$ & $B_{1}$ & Micélio \\
2025 & 10 & 7,5 & - & - \\
2026 & 0,2 & 0,15 & - & - \\
2027 & - & - & 80 & 60 \\
2028 & 8,0 & 6,0 & 400 & 300 \\
2029 & 40 & 30 & 400 & 300 \\
\hline
\end{tabular}

Após 9 anos, em 1983 o quadro da produção de aflatoxinas nestas linhagens foi bem diferente (dados não publicados), como mostra a Tabela 2 . 
Tabela 2. Produção de aflatoxinas $B_{1}$ e $G_{1}$ no meio de cultura e no micélio por linhagens de A. flavus iso ladas por FONSECA et alie (1974) após 9 anos de estocagem

Linhagem

Produção de aflatoxinas (ppm)

Linhagen Meio de cultura ${ }^{B}$

G1 Micélio

\begin{tabular}{ccccc} 
& $B_{1}$ & $G_{1}$ & $B_{1}$ & $G_{1}$ \\
\hline 2025 & - & - & - & - \\
2026 & 8 & - & 38 & - \\
2027 & - & - & 0,4 & - \\
2028 & 0,9 & 0,67 & 3,5 & 2,6 \\
2029 & - & - & - & - \\
\hline
\end{tabular}

Como podemos ver, aquelas linhagens que eram altamente produtoras de aflatoxinas, jā não produziram mais e em outras a produção caiu significantemente. Esse fato jā havia sido observado anteriormente (FONSECA) I/.

SCHROEDER E CARLTON (1973) isolaram uma linhagem de A. flavus, de grãos de pimenta, acumulando apenas aflatoxina $B_{2}$, quando crescido em vārios substratos naturais. Não há relatos anteriores de linhagens capazes de pro duzir grandes quantidades de $B_{1}$ e $G_{1}$ exclusivamente. Quando

I/ FONSECA, H., 1980. Comunicação pessoal. 
esta linhagem foi isolada, ela produzia 900 ug/g de aflatoxina. Com subculturas sucessivas, a produção declinou rapidamente, produzindo depois, $200 \mathrm{ug} / \mathrm{g}$. Em nenhum momento esta linhagem produziu aflatoxina $B_{1}, G_{1}$ ou $G_{2}$.

BOLLER e SCHROEDER (1974) trabalhando com co nidios secos de A. parasiticus e A. Glavus, estocados em la boratōrio, a fim de verificar se a habilidade de produzir aflatoxina decrescia com o tempo de estocagem e observaram que a habilidade de produzir aflatoxina nestas condições, permanece inalteradas, por períodos de até 34 meses. A produção de aflatoxina foi determinada mensalmente e foi obser vado que não houve uniformidade na produção de toxina de ca da isolado nas diferentes épocas do teste.

\subsection{Estudos Fisiológicos.}

DIENER e DAVIS (1969), pesquisando os fatores ambientais que afetam a produção de aflatoxina em A. blavus tais como: temperatura, umidade relativa, oxigênio e dióxido de carbono, verificaram que a temperatura minima, para produção de aflatoxina é de $12^{\circ} \mathrm{C}$, e a máxima é de $42^{\circ} \mathrm{C}$, es tando a ótima entre 24 e $30^{\circ} \mathrm{C}$. Quanto à umidade relativa, verificaram que 0 limite inferior era de $85 \%$ para o crescimento do fungo e produção de toxina. A concentração reduzida de oxigênio, reduziu a produção de aflatoxina; por 
outro lado, a produção de aflatoxina decresceu com o aumento da concentração de dióxido de carbono.

DAVIS et alii (1966) desenvolveram um meio semi-sintētico para a produção de aflatoxina que consiste em: $20 \%$ de sacarose e $2 \%$ de extrato de levedura. Este meio proveu todos os ingredientes necessārios para a produção de altos níveis de aflatoxinas. Não foi necessārio nenhum ingrediente adicional, nem ajustamento do pH inicial.

HESSELTINE et alii (1966) estudando a forma ção de aflatoxinas por A. blavus, verificaram que hā grande diferença nas capacidades das 1 inhagens para produzir aflatoxinas, mesmo por linhagens jā conhecidas como produtoras, e essas diferenças ocorrem em função do meio de cultivo ou substrato empregado.

NORTHOLT et alii (1977) conduziram um estudo para investigar a hipótese de que, as diferenças nas temperatuas ótimas para a produção de aflatoxina, relatada por vários autores, seriam por causa das diferenças nas linhagens de A. flavus, hipótese esta confirmada pelos resultados do experimento. Além disso, verificaram que outro fator, que determina a temparatura ótima, é o tipo de substrato.

MOREAU (1979) revisando vārios autores verificou que o fungo A. blavus pode utilizar uma grande 
variedade de carboidratos simples ou polissacarídeos como o amido, carboximetilcelulose como sua única fonte de carbono. O crescimento de A. flavus pode ser profundamente influenciado pela natureza da fonte de nitrogēnio, e além disso, este fungo possui a habilidade de produzir nitritos e nitratos a partir do nitrogēnio orgänico por um processo de nitrificação.

REDDY et alii (1979), testaram o efeito de vārias fontes simples e complexas de nitrogēnio e carbono na formaçãa de aflatoxina. Segundo estes autores, a habili dade de utilizar fontes de nitrogênio orgânico ou inorgānico e de carbono para a formação de toxina, depende da linhagem do fungo, da composição do meio, do pH e da temperatura.

De acordo com LIN et alii (1980), a linhagem do organismo produtor de aflatoxina e os fatores ambientais e nutricionais, têm um pronunciado efeito na produção total e nas proporções relativas de aflatoxina $B_{1}$ e $G_{1}$.

Segundo WICKLOW et alii (1981), o cultivo de isolados produtores de toxinas no substrato natural, como o milho autoclavado, prova ser um teste mais seguro do potencial de produção de aflatoxina do que um meio semi-sintético. 


\subsection{Estudos Genéticos}

Estudos genéticos em A. blavus e A. parasiticus, só podem ser realizados com a colaboração do ciclo parassexual, fenōmeno este descoberto por PONTECORVO e ROPER (1952) em A. nidulans. 0 passo essencial do ciclo parassexual consiste em: heterocariose, diploidização, recombinação mitótica e haploidização (PONTECORVo et alii). PAPA (1973) observou pela primeira vez a existēncia do ciclo parassexual em A. Glavus Link. Mais tarde PAPA (1978), observou o ciclo parassexual em A. parasiticus.

MURAKAMI et alii (1968) testando vārias linhagens de Aspergillus, de uso industrial, verificaram que as mesmas não eram produtoras de aflatoxina. Contudo, algumas linhagens não industriais, que eram conhecidas como aflatoxigēnicas, falharam em produzir aflatoxina. Segundo estes autores, hā uma diferença na produtividade de aflatoxina entre uma linhagem e seus setores segregantes. Como no caso citado por estes autores, da linhagem RIB 4016 não produtora de aflatoxina, seu segregante RIB 4028 produziu, por outro lado, um forte produtor RIB 4009 , deu um segregante RIB 40026 não produtor.

ELLIS (1969) descobriu um mutante laranjaamarelo de $A$. parasiticus, produzindo duas vezes mais aflatoxina $B_{1}$ e $G_{1}$ que a linhagem selvagem. 
LEAICH e PAPA (1974) isolaram mutantes de A. blavus, para determinar a extensão da variabilidade de produzir aflatoxina. Não observaram correlação entre necessidade nutricional e produção de aflatoxina. Uma anālise estatistica demonstrou que as diferenças de produção de aflatoxinas $B_{1}$ e $B_{2}$ são significativas entre os mutantes estudados, classificando-os em três nîveis: alto, intermediārio e baixo.

PAPA (1976) identificou sete grupos de ligação em A. blavus, por meio do ciclo parassexual. Mais tarde PAPA (1977) identificou um gene recessivo controlando o acúmulo de aflatoxina $B_{2}$ maior que $B_{1}$, e este mostrou estar ligado ao "loco" histidina no grupo de ligação VIII. Pela segregação independente do "loco" histidina e por outras marcas gênicas localizadas nos grupos de ligação I ao VII, oito grupos de ligação no fungo A. Glavus puderam ser estabelecidos. Um mutante relativamente estável acumulando altos niveis de aflatoxina $B_{2}(5000 \mathrm{ug} / \mathrm{g}$ de peso seco micelial) e baixos níveis de aflatoxina $B_{1}(600 \mathrm{ug} / \mathrm{g}$ de peso se co micelial) foi analisado pelo ciclo parassexual revelando um "loco" gênico envolvido na biossintese de aflatoxina.

MESSIAS et alii (1976) trabalhando com três linhagens de A. Glavus Link. diferindo na produção de aflatoxinas, estudaram aspectos relacionados com o ciclo 
parassexual e a produção de aflatoxinas. Com os mutantes morfológicos e auxotróficos obtidos, observaram a compatibi lidade entre as linhagens de diferentes origens, formando diplóides entre elas. A produção variou nas diferentes linhagens (mutantes diplóides e segregantes haplóides) e não houve relação com alterações devidas às marcas nutricionais, antes foi verificado uma grande divergēncia na produção de aflatoxinas pelos segregantes obtidos a partir das linhagens diplóides. MESSIAS (1977) verificou que o caráter pro dução de aflatoxinas em A. Glavus è complexo, e possivelmente, muitos genes estão envolvidos.

GUSSAK et alii (1977), examinando oito isolados de A. Glavus e A. parasiticus, para detectar a presen ça de partículas semelhantes a vírus (VLP "virus - like particles"), encontraram-nas somente em linhagens de A. Glavus. Foi estudada a parassexualidade na linhagem aflatoxigênica de A. Glavus contendo VLP, porém, não foi detecta da nenhuma evidência de uma correlação entre produção ou não de aflatoxina e a presença das partículas semelhantes a vírus.

HOLLINGS (1978), revisando vários autores, concluiu que a produção de micotoxinas, raramente está correlacionada com a presença ou ausência de um micovírus. Nes ta revisão ele cita o exemplo de duas espécies de Asper gillus infectadas com vírus e produzindo aflatoxina, uma 
Iinhagem de A. Glavus infectada com vírus, sem produzir, e também dois isolados de A. parasiticus, aparentemente Iivres de vîrus, ambos produzindo aflatoxina.

Por outro lado, Bousquet, em 1973 (citado por HOLLINGS, 1978) relatou uma correlação positiva entre a pro dução da toxina piriculol pelos fungos que invadem o arroz (Pyricularia oryzae) e a presença de VLP.

PAPA (1979), obteve catorze mutantes não aflatoxigênicos, ao tratar conídios de seis mutantes de coloração de esporos e auxotróficos, com nitrosoguanidina.Tes tes de complementação dos diplóides revelaram que a maioria destes mutantes para aflatoxinas não são alēlicos. A complementação não ocorreu entre todos os mutantes testados, e a maioria foi recessiva nos diplóides, com exceção do mutan te $a b l-1$.

BENNETT et alii (1980) empregaram um método de exposição breve dos esporos deA. parasiticus em $p$-fluorofenilalanina ( $p F A)$, a fim de recuperar marcas auxotróficas a partir dos diplóides heterozigotos. Foram examinados sete diplóides heterozigotos com trēs marcas na coloração de esporos e oito marcas auxotróficas. Além destes, foram analisados mais dois mutantes bloqueados na produção de aflatoxinas, acumulando detectáveis precursores de aflatoxinas. Houve evidência de ligação entre uma marca auxotrófica 
e uma marca de coloração de esporos, mas nenhuma evidência foi encontrada para ligação entre os mutantes bloqueados na sintese de aflatoxina e as outras marcas estudadas. Neste experimento os autores realizaram o primeiro estudo comparativo de superfície de ornamentação entre conídios haplóides, heterocarióticos e diplóides de A. parasiticus, com microscopia eletrōnica tipo "scanning". Suas observações indicaram que as superfícies de ornamentação foram similares para estes tipos de esporos de A. parasiticus.

PAPA (1982) descobriu um mutante de A. Glavus acumulando àcido norsolorínico e aproximadamente $50 \%$ menos aflatoxina que a linhagem parental, após o tratamento dos conidios com nitrosoguanidina. O gene nor controlando este fenōtipo mutante, foi recessivo e ligado ao abl-1 e leu no grupo de ligação VII. Homozitogos diplóides para nor foram similares aos haplóides em acumular àcido norsolorínico. A anālise de recombinantes diplóides e haplóides mostraram que afl-1 e nor foram distais para leu no mesmo braço cromossômico.

\subsection{Estudos Bioquímicos}

CODNER et alii (1963) verificaram que existem linhagens produtoras de aflatoxinas, desprovidas de dois de seus constituintes normais $G_{1}$ e $G_{2}$. Sendo assim, este fato sugere que os tipos de aflatoxinas podem seguir uma se quência de processos enzimáticos. 
LEE et alii (1971) ao analisarem um mutante de A. parasiticus, observaram que este mutante elaborou $80 \%$ menos aflatoxina que a linhagem parental e um grande acümu10 de ácido norsolorínico, que poderia ser um possível intermediārio na sīntese.

Da mesma forma, DONKERSLOOT et alii (1972)es tudando um outro mutante de A. parasiticus, tambēm prejudicado na biossintese de aflatoxina, observou que este acumulava a averufina, que tambēm poderia ser intermediārio da biossintese.

Mais tarde SINGH e HSIEH (1977) utilizando mutantes de A. parasiticus marcados com "C 14 ", bloqueados na sintese de aflatoxinas, propuseram a via biossintética da aflatoxina $B_{1}$ como sendo: acetato $\rightarrow$ averufina $\rightarrow$ acetato versicona $\rightarrow$ versicolorina $A \rightarrow$ esterigmatocistina $\rightarrow$ aflatoxina $\mathrm{B}_{1}$.

De acordo com LIN (1980), o caminho mais pro vável da biossíntese da aflatoxina é: 1 acetil CoA + 9 malonil $\mathrm{COA} \rightarrow \bar{a} \mathrm{cido}$ norsolorínico $\rightarrow$ averufina $\rightarrow$ acetato versiconal $\rightarrow$ versicolorina $A \rightarrow$ esterigmatocistina $\rightarrow$ aflatoxina.

SCHMIDT et alii (1977) utilizaram comparações eletroforéticas de enzimas miceliais de linhagens produtoras e não produtoras de aflatoxina. Os dados deste 
experimento sugeriram que hā um certo grau de similaridade entre as linhagens de A. flavus e A. parasiticus, $e$ isto poderia ser o resultado de um ancestral comum ou de uma oca sional hibridização das duas espécies. Segundo aqueles autores é possīvel que nestas linhagens, onde falta um estágio sexual, as variações ocorram via ciclo parassexual.

\subsection{Estudos Morfológicos e Citológicos}

LEAICH e PAPA (1975) analisando citologicamente os conídios de A. Glavus, observaram que haplóides bi nucleados $(N+N)$ e diplóides uninucleados $(2 N)$ apresentam o mesmo volume conidial, pois o haplóide tem quantidade prá ticamente equivalente de DNA em relação ao diplóide.

Vários autores tem tentado correlacionar cer tas peculiaridades morfológicas presentes em linhagens toxigēnicas, tais como: a presença de esferócitos, hipertrofia de hifas, as séries de fiálides, e outros traços significantes com sua toxigenicidade (TORRES et alii, 1980).

MURAKAMI et alii (1968) pesquisando as diferenças morfológicas em Aspergillus entre as produtoras e não produtoras de aflatoxinas, observaram as seguintes características nas linhagens produtoras: cabeça conidial com pigmentação verde, mesmo em culturas idosas, lado reverso da colónia enrugado e pigmentado, presença de esclerócio, 
vesícula globosa ou subglobosa, esterigma geralmente biseriada e conidióforo com parede enrugada e com alta pigmentação. Estes autores analisando vārias linhagens, concluĩram que as características micológicas, descritas acima, são necessārias aos fungos para a produção de aflatoxina, mas nem sempre os fungos que possuem tais características são produtores de aflatoxinas.

MOREAU (1979) revisando vārios autores verificou que os isolados com conidióforos enrugados e fiálides biseriadas geralmente são colocados nas espécies de A. Glavus, enquanto aqueles com conidióforos lisos e fiālides uni seriadas são classificadas como A. parasiticus.

TORRES et alii (1980) estudando a produção de aflatoxinas em quatro linhagens de Aspergillus, crescendo em trigo moído e umidecido, verificaram evidencia de um decréscimo na sintese de aflatoxina, acompanhada por trocas morfológicas após subculturas sucessivas. Foi observado que, através destas subculturas, ocorre uma redução de certos elementos estruturais e um aumento no desenvolvimento de outras. A quantidade do micélio vegetativo aumentou, tornando-se altamente predominante, dando uma aparência cotonosa às colōnias. As vesículas diminuīram no nümero e tamanho, prejudicando a capacidade reprodutiva. Com estas observações, concluĩram que o complexo enzimático do fungo 
perdeu a capacidade para a sintese de aflatoxinas, e a perda foi acompanhada por trocas morfológicas.

ABOU-GABAL e FAGERLAND (1981) analisando a ultraestrutura de A. parasiticus, associaram a presença de clamidosporo com uma maior produção de aflatoxinas. Segundo estes autores, a presença de clamidosporo, foi devido às condições adversas do meio de cultura e, desta forma, os clamidosporos converteram os nutrientes em metabólitos secundārios ao invés de massa celular.

REIB (1982) investigando a relação entre conidiogēnese e o metabolismo secundārio em A. parasiticus, verificou que consideráveis quantidades de aflatoxina $B_{1}$ são sintetizadas e somente quando a formação de conĩdios é relativamente intensa.

BHATNAGAR et alii (1982) pesquisaram o papel dos blastosporos na proteção de A. parasiticus, dos altos níveis de aflatoxinas. Os dados obtidos sugerem que a formação dos blastosporos é um mecanismo adaptativo, pelo qual os fungos se protegem dos altos niveis de aflatoxinas. Estas células provavelmente têm permeabilidade reduzida e, portanto, a aflatoxina extracelular pode fazer pouco dano ao sistema. 0 desenvolvimento de parede espessa durante a fase estacionāria de crescimento é observada em outros organismos produtores de metabolismo secundārio. 
WICKLOW e SHOTWELL (1982) estudando a distri buição de aflatoxina entre conĩdios e esclerócios de A. Glavus e A. parasiticus, verificaram que os níveis totais de aflatoxinas, tanto nos conídios como nos esclerōcios, podem variar grandemente, entre as linhagens produtoras de aflatoxinas. Isto é esperado, uma vez que isolados de A. flauus e A. parasiticus diferem na capacidade de produzir aflatoxina.

DOYLE e MARTH (1978 a, b e c) realizaram um minucioso estudo sobre a habilidade do micélio de A. parasiticus em degradar a aflatoxina. Destes estudos foram tiradas as seguintes conclusões: 1) a aflatoxina pode ser de gradada pelo mesmo fungo que a produz, e a habilidade do mi célio em degradar a toxina, aumenta com o aumento da produção da mesma (DOYLE e MARTH, 1978a); 2) micélios de uma mesma linhagem crescidos sob condições similares, podem va riar na habilidade de degradar a aflatoxina pois, variação similar póde ser notada na produção de aflatoxina, quando crescidos nas mesmas condições ambientais (DOYLE e MARTH, 1978b); 3) a habilidade do micélio em degradar a aflatoxina, foi influenciada pela temperatura e $\mathrm{pH}$, o que sugere que - fator ou fatores responsáveis pela degradação é ou são en zimas (DOYLE e MARTH, 1978c). 
DOYLE e MARTH (1979) mostraram tambēm, que hă uma relação positiva da atividade da peroxidase e a degradação de aflatoxina.

RAO et alii(1980), confirmaram esta evidēncia ao observarem que a peroxidase encontrada nos lipidios foi aumentada sob condições de reduzida produção de aflatoxina, este fato provavelmente ocorreu por causa da maior disponibilidade de NADPH. Por estes dados parece que a bai xa atividade de lipídio e dos nucleotídios são favoráveis para a ótima produção de aflatoxina.

BHATNAGAR et alie (1982) tambēm observaram que a elevada atividade da peroxidase coincidiu com o período máximo de produção de aflatoxina. De acordo com es tes autores a peroxidase foi capaz de degradar as aflatoxinas em níveis bem altos e a alta atividade de GDH-NADP estaria associada à germinação dos blastosporos. 


\section{MATERIAL E METODOS}

o experimento foi desenvolvido no laboratório de Micotoxinas do Departamento de Tecnologia Rural e no Departamento de Genética da Escola Superior de Agricultura "Luiz de Queiroz" (ESALQ-USP - Piracicaba).

3.1. Organismo Produtor de Aflatoxinas

Linhagens produtoras de aflatoxinas foram isoladas a partir de amendoins contaminados, provenientes do Estado de São Paulo

0 isolamento dos fungos seguiu a seguinte téc nica descrita por FONSECA et alie (1974): $10 \mathrm{~g}$ do material foi tomado e transferido assepticamente para frascos de erlenmeyer contendo $90 \mathrm{ml}$ de àgua esterilizada. Os frascos foram agitados cuidadosamente, obtendo uma suspensão de es poros de $10^{-1}$. A seguir, $1 \mathrm{ml}$ dessa solução foi tomada, e 
transferida para tubos de cultura contendo $9 \mathrm{ml}$ de ägua es terilizada. Esta operação foi repetida, de modo a obter di luições de $10^{-2}, 10^{-3}, 10^{-4}, 10^{-5}$ e $10^{-6}$. Das diluições $10^{-5}$ e $10^{-6}$ foram tomadas $1 \mathrm{ml}$, e de $10^{-3}$ e $10^{-4}$ foram tomadas $0,1 \mathrm{ml}$. Estas diluições foram colocadas em placas de Petri esterilizadas, com duas repetições para cada diluição. O meio de Czapeck foi acrescentado e as placas foram agitadas levemente, para dar uma distribuição uniforme aos esporos por todo o meio. As placas foram incubadas à $28^{\circ} \mathrm{C}$, durante 4 a 6 dias. As colōnias foram isoladas à medida que foram aparecendo nas placas. Colónias do grupo A. blavus puderam ser distinguidas, pelas suas caracteristicas macroscōpicas, como: conidióforos longos, abundante pro dução de esporos de coloração verde-oliva e verde amarelada.

\subsection{Meios de Cultivo}

As colōnias crescidas no meio de Czapeck foram isoladas assepticamente, tomando-se por base as caracte risticas citadas acima, sendo transferidas para o meio de Czapeck modificado por ser um meio mais rico, que proporcio na um melhor desenvolvimento ao fungo.

Seguindo as instruções de RAPER e FENNELL (1965), oito colónias do grupo A. Glavus foram isoladas do amendoim, cada colónia recebeu uma numeração, à medida em 
que foram isoladas. Depois de testar cada isolado quanto à aflatoxigenicidade, trēs linhagens de nümeros 2,4 e 6 , foram escolhidas para trabalhar neste experimento.

3.2.1. Meio de Czapeck, citado por RAPER e FENNELL $(1965):$

$\mathrm{NaNO}_{3} \ldots \ldots \ldots \ldots, 3,0 \mathrm{~g}$

$\mathrm{K}_{2} \mathrm{HPO}_{4} \cdots \cdots \cdots \cdots, 1,0 \mathrm{~g}$

$\mathrm{MgSO}_{4} \cdot 7 \mathrm{H}_{2} \mathrm{O} \ldots \ldots \ldots 0,5 \mathrm{~g}$

$\mathrm{KCl} \ldots \ldots \ldots \ldots \ldots, 0,5 \mathrm{~g}$

$\mathrm{FeSO}_{4} \cdot 7 \mathrm{H}_{2} \mathrm{O} \ldots \ldots \ldots 0,01 \mathrm{~g}$

Sacarose ........30,0 g

Agar ......... 15,0 g

Agua destilada .... $1000 \mathrm{ml}$

3.2.2. Meio de Czapeck modificado por FONSECA et alii (1974):

$\mathrm{NaNO}_{3} \ldots \ldots \ldots \ldots, 3,0 \mathrm{~g}$

$\mathrm{K}_{2} \mathrm{HPO}_{4} \ldots \ldots \ldots \ldots, 1,0 \mathrm{~g}$

$\mathrm{MgSO}_{4} \cdot 7 \mathrm{H}_{2} \mathrm{O} \ldots \ldots \ldots 0,5 \mathrm{~g}$

$\mathrm{KCl} \ldots \ldots \ldots \ldots \ldots, 0,5 \mathrm{~g}$

$\mathrm{FeSO}_{4} \cdot 7 \quad \mathrm{H}_{2} \mathrm{O} \ldots \ldots .0,01 \mathrm{~g}$.

Sacarose ....... $200 \mathrm{~g}$

Extrato de levedura. 7,0 g

Agar ......... 15,0 g

Agua destilada ... $1000 \mathrm{ml}$ 
3.3. Meio de Cultura para Produção de Aflatoxina.

As linhagens foram testadas, na capacidade de produzir aflatoxina, no seguinte meio de cultura.

3.3.1. Meio "YES", descrito por DAVIS et alii(1966):

Extrato de levedura ...... $2 \%$

Sacarose .............20\%

Agua destilada .........1000 ml

Os fungos permaneceram neste meio por um período de 10 dias, $\bar{a} 28^{\circ} \mathrm{C}$, e em seguida fez-se a extração da toxina.

\subsection{Métodos para Conservação de Fungos}

Os fungos foram mantidos em dois métodos de preservação como estudados por FENNELL (1960).

3.4.1. Método de transferéncia periódica:

Os fungos foram repicados periodicamente, $\bar{a}$ medida que o substrato foi se esgotando. 0 meio utilizado foi de Czapeck modificado em tubos de cultura inclinados. os fungos foram mantidos à temperatura de $28^{\circ} \mathrm{C}$. 
3.4.2. Método de preservação em óleo mineral

Os fungos cresceram em frascos de $10 \mathrm{ml}$ com meio de Czapeck inclinado, à temperatura de $28^{\circ} \mathrm{C}$. Quando a cultura atingiu toda a extensão do meio, ela foi coberta com óleo mineral esterilizado e o frasco foi tampado com tampa de borracha. As culturas foram conservadas à temperatura ambiente, e foram revigoradas em meio de Czapeck modificado, antes de serem usadas.

\subsection{Extração das Aflatoxinas.}

A extração das aflatoxinas, do meio de cultura e do micélio, foram efetuadas segundo a metodologiades crita por FONSECA èt alii (1974):

3.5.1. Extração do meio de cultura

0 meio de cultura foi filtrado cuidadosamente em funil Büchner, com papel de filtro Whatman nọ l, à văcuo de trompa, sendo o meio recebido em kitazato. Uma al quota de $5 \mathrm{ml}$ do meio foi tomada e transferida para um funil de separação, adicionando-se $25 \mathrm{ml}$ de clorofórmio para extrair a aflatoxina. A fase inferior foi coletada em béquer, adicionando-se $\mathrm{Na}_{2} \mathrm{SO}_{4}$ anidro para remover a umidade. 0 extrato foi passado para um frasco escuro, e guardado em refrigerador, para sua posterior cromatografia em placas de camada delgada de silicagel-G. 
3.5.2. Extração do micēlio

0 micélio foi passado cuidadosamente, com $50 \mathrm{ml}$ de acetona a $70 \%$, para um balão extrator de Soxhlet e refluxado com este mesmo solvente durante uma hora e trinta minutos. A seguir, o solvente foi passado para um funil de separação de $250 \mathrm{ml}$, lavando o balão extrator com $20 \mathrm{ml}$ de àgua destilada. A extração da toxina foi feita com duas porções de $25 \mathrm{ml}$ de clorofórmio. A fase inferior foi coletada num bequer, adicionando-se $\mathrm{Na}_{2} \mathrm{SO}_{4}$ anidro. 0 extrato foi passado para um frasco escuro, e guardado em refrigerador, para sua posterior cromatografia.

\subsection{Determinação Quantitativa das Aflatoxinas.}

Aliquotas dos extratos, juntamente com padrões das aflatoxinas, foram aplicados em placas cromatográficas cobertas com camada de $0,5 \mathrm{~mm}$ de espessura de silicagel-G. Os cromatogramas foram desenvolvidos com Tolueno: Acetato de etila:Acido fórmico 90\% (30:15:5), conforme descrito por scotT et alii (1970). A leitura da placa foi feita sob luz ultravioleta de ondas longas (365 $\mathrm{nm}$ ), de uma lâmpada Philips, tipo HPW, 125 watt, numa câmara escura. A quantificação das aflatoxinas seguiu a técnica de coomes e FEUELL (1965), que consiste numa avaliação visual de diluição até extinção. Para determinar a quantidade de aflatoxi nas produzidas pelo fungo, o seguinte cálculofoi utilizado: 
ppm aflatoxina $B_{1}=\frac{0,4 \times D}{P \times V}$

ppm aflatoxina $G_{1}=\frac{0,3 \times D}{P \times V}$

onde:

$D=$ Volume total de solvente necessārio para extrair e diluir ou concentrar a amostra

$P=$ Peso da amostra

$V=$ Volume, em microlitros, da menor aliquota em que foi observada fluorescéncia, no limite de sua visibilidade na placa.

os valores 0,4 e 0,3 que correspondem às aflatoxinas $B_{1}$ e $G_{1}$, respectivamente, é decorrente do fato de que, nas condições do método estabelecidas por coomes e FEUELL (1965), as menores quantidades das aflatoxinas B 7 e G que podemser observadas fluorescéncias na placa é de 0,0004 e 0,0003 microgramas, respectivamente.

Os padrões das aflatoxinas $B_{1}$ e $G_{1}$ foram obtidas no Departamento de Tecnologia Rural da Escola Superior de Agricultura "Luiz de Queiroz" (ESALQ-USP - Piracica ba). 


\subsection{Anālise Microscōpica}

As observações microscópicas dos fungos foram realizadas no Laboratório de Genética de Microrganismos do Departamento de Genética da Escola Superior de Agricultura "Luiz de Queiroz" (ESALQ-USP - Piracicaba).

A técnica utilizada foi o cultivo em lâmina: em placas contendo meio de Czapeck modificado sōlido, colocou-se uma laminula esterilizada. O fungo foi inoculado ao redor da laminnula a uma distāncia aproximada de $1 \mathrm{~mm}$ dela. Este procedimento foi realizado para cada linhagem. Após 24 horas de incubação o micélio se desenvolveu crescendo so bre a laminula. Esta foi retirada e colocada sobre lámina com uma gota do corante safranina alcoólica, e em seguida foi levada ao microscópio óptico. As estruturas das hifas, conídios e aparelho conidial foram observadas.

3.7.1. Corante safranina-0,10\%

Safranina $\ldots \ldots \ldots \ldots 1,0 \mathrm{~g}$

Alcool $95 \% \ldots \ldots \ldots 100 \mathrm{ml}$

Retirou-se $10 \mathrm{ml}$ da solução de safranina alcoōlica - 1,0\% e completou-se para $90 \mathrm{ml}$ de água destilada. 
4. RESULTADOS

4.7. Produção Inicial de Aflatoxinas

A Tabela 3 apresenta a produção inicial de aflatoxinas das três linhagens, selecionadas com suas respectivas numerações.

Tabela 3. Produção inicial de aflatoxinas das linhagens do grupo A. Glavus, isoladas do amendoim (Média de duas repetições)

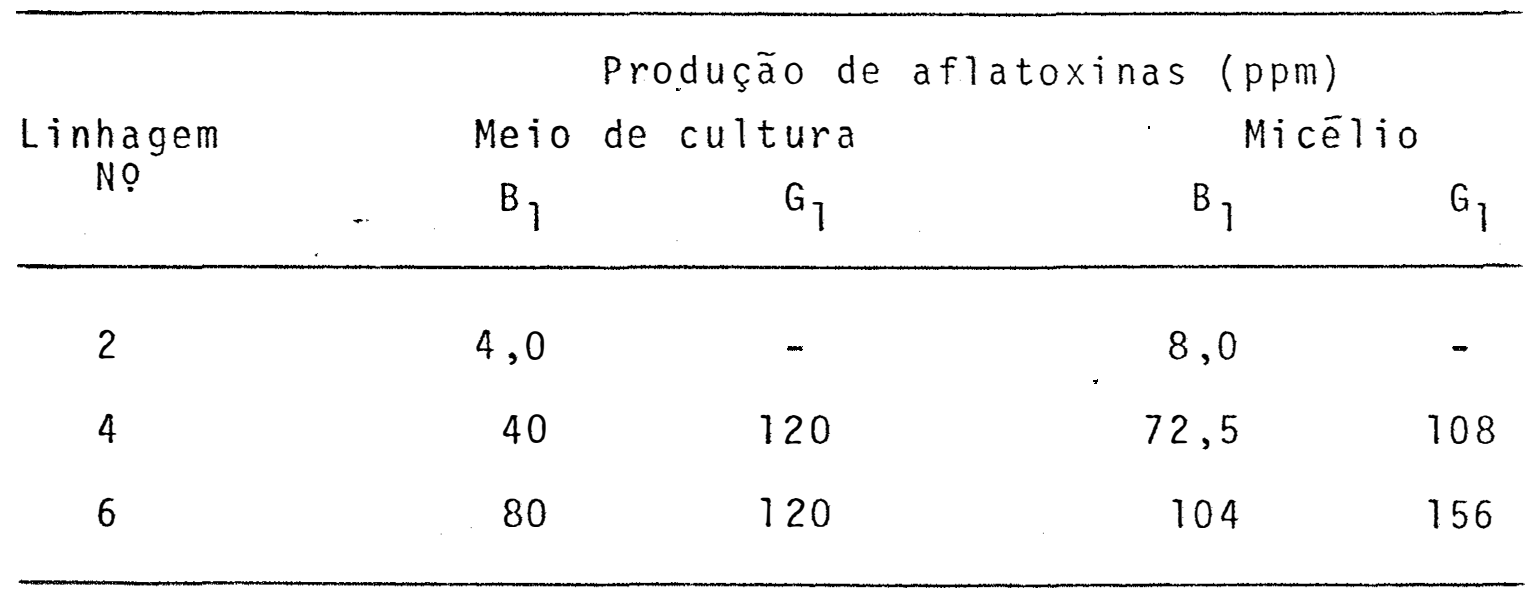


Como mostra a Tabela 3 , as linhagens 4 e 6 produziram aflatoxinas do tipo $B$ e $G$, enquanto que a linhagem 2 só produziu aflatoxina do tipo B; as aflatoxinas do tipo $B_{2}$ e $G_{2}$ também foram produzidas, mas não foram determinadas quantitativamente. Todas as linhagens produziram aflatoxinas no meio de cultura e no micélio. A linhagem 2 foi uma fraca produtora de aflatoxina, quando comparada com a linhagem 4 e 6 . Esta ūltima produziu a maior quantidade de aflatoxinas tanto no meio como no micélio.

4.2. Produção de Aflatoxinas pelas Linhagens Mantidas em oleo Mineral

Neste experimento, que durou 280 dias, a pro dução de aflatoxinas foi determinada nos seguintes intervalos de tempo: $15,30,60,90,120,150,180$ e 280 dias. As Tabelas 4,5 e 6 apresentam a produção de aflatoxinas das linhagens 2,4 e 6 respectivamente, mantidas em óleo mineral, durante este periodo. 
Tabela 4. Produção de aflatoxinas da linhagem 2, mantida em óleo mineral (Média de duas repetições)

\begin{tabular}{lccccc}
\hline \multirow{2}{*}{$\begin{array}{c}\text { Tempo } \\
\text { (dias) }\end{array}$} & \multicolumn{3}{c}{ Produção de aflatoxinas } & \multicolumn{2}{c}{ (ppm) } \\
& B $_{1}$ & $G_{1}$ & $B_{1}$ & $G_{1}$ \\
\hline 15 & 4,0 & - & 1,9 & - \\
30 & 0,8 & - & 1,2 & - \\
60 & 6,0 & - & 8,8 & - \\
90 & 2,5 & - & 1,1 & - \\
120 & 6,0 & - & 1,5 & - \\
150 & 0,8 & - & 0,3 & - \\
180 & 4,0 & - & 6,3 & 4,0 & - \\
\hline
\end{tabular}


Tabela 5. Produção de aflatoxinas da linhagem 4, mantida em óleo mineral (Média de duas repetições)

\begin{tabular}{|c|c|c|c|c|}
\hline \multirow{2}{*}{$\begin{array}{l}\text { Tempo } \\
\text { (dias) }\end{array}$} & \multicolumn{2}{|c|}{$\begin{array}{l}\text { Produção de } \\
\text { Meio de cultura }\end{array}$} & \multicolumn{2}{|c|}{$\begin{array}{l}\text { (ppm) } \\
\text { Micélio }\end{array}$} \\
\hline & $\mathrm{B}_{1}$ & $\mathrm{G}_{1}$ & ${ }^{B} 1$ & $G_{1}$ \\
\hline 15 & 80 & 60 & 80 & 35 \\
\hline 30 & 20 & 90 & 209 & 180 \\
\hline 60 & 30 & 75 & 53 & 35,3 \\
\hline 90 & 120 & 180 & 100 & 150 \\
\hline 120 & 60 & 120 & 40 & 60 \\
\hline 150 & 60 & 180 & 106 & 160 \\
\hline 180 & 40 & 60 & 27,3 & 61,4 \\
\hline 280 & 80 & 120 & 104,7 & 126,2 \\
\hline
\end{tabular}


Tabela 6. Produção de aflatoxinas da linhagem 6 , mantida em óleo mineral (Média de duas repetições)

\begin{tabular}{lcccc}
\hline & \multicolumn{3}{c}{ Produção de aflatoxinas } \\
$\begin{array}{l}\text { Tempo } \\
\text { (dias) }\end{array}$ & Meio de cultura & \multicolumn{2}{l}{ Micétio } \\
& $B_{1}$ & $G_{1}$ & $B_{1}$ & $G_{1}$ \\
\hline 15 & 180 & 180 & 209 & 313 \\
30 & 80 & 120 & 61 & 257 \\
60 & 40 & 240 & 129 & 193 \\
90 & 200 & 300 & 161 & 173 \\
120 & 80 & 240 & 133 & 200 \\
150 & 160 & 480 & 261 & 277 \\
180 & 133 & 300 & 196 & 240 \\
280 & 120 & 180 & 291 & 364 \\
\hline
\end{tabular}


De acordo com as Tabelas 4,5 e 6 , podemos observar que não houve uma produção uniforme de aflatoxinas durante os períodos estudados, antes, ela variou grandemente. Não houve também redução na quantidade de aflatoxina, com a estocagem de 280 dias, em óleo mineral. A linhagem 2 continuou produzindo pouca aflatoxina, enquanto que as linhagens 4 e 6 continuaram produzindo quantidades relativamente grandes. A aflatoxina continuou sendo produzida tanto no meio como no micélio, e as linhagens que produziam aflatoxinas do tipo $B$ e G continuaram produzindo, a linhagem 2 em nenhum momento deste experimento, produziu aflatoxina $G$. Em geral a aflatoxina $G_{1}$ foi produzida em maior quantidade que a $B_{1}$ pelas linhagens 4 e 6 .

Para visualizar a variação da produção de aflatoxinas nestas linhagens, durante este período, os dados das Tabelas 4, 5 e 6 foram passados para um gráfico, portanto as Figuras 1,2 e 3 ilustram estes dados, respectivamente. 


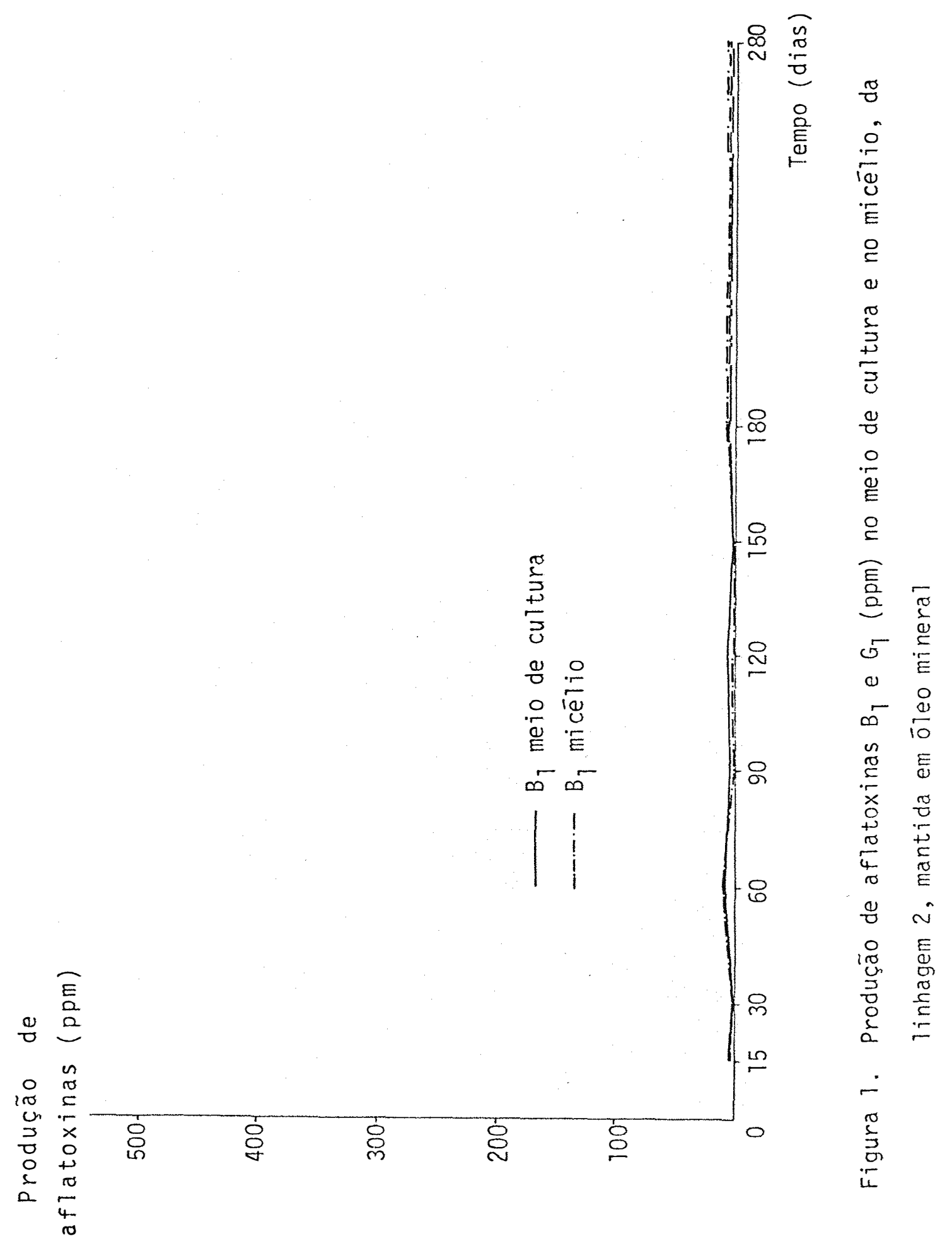




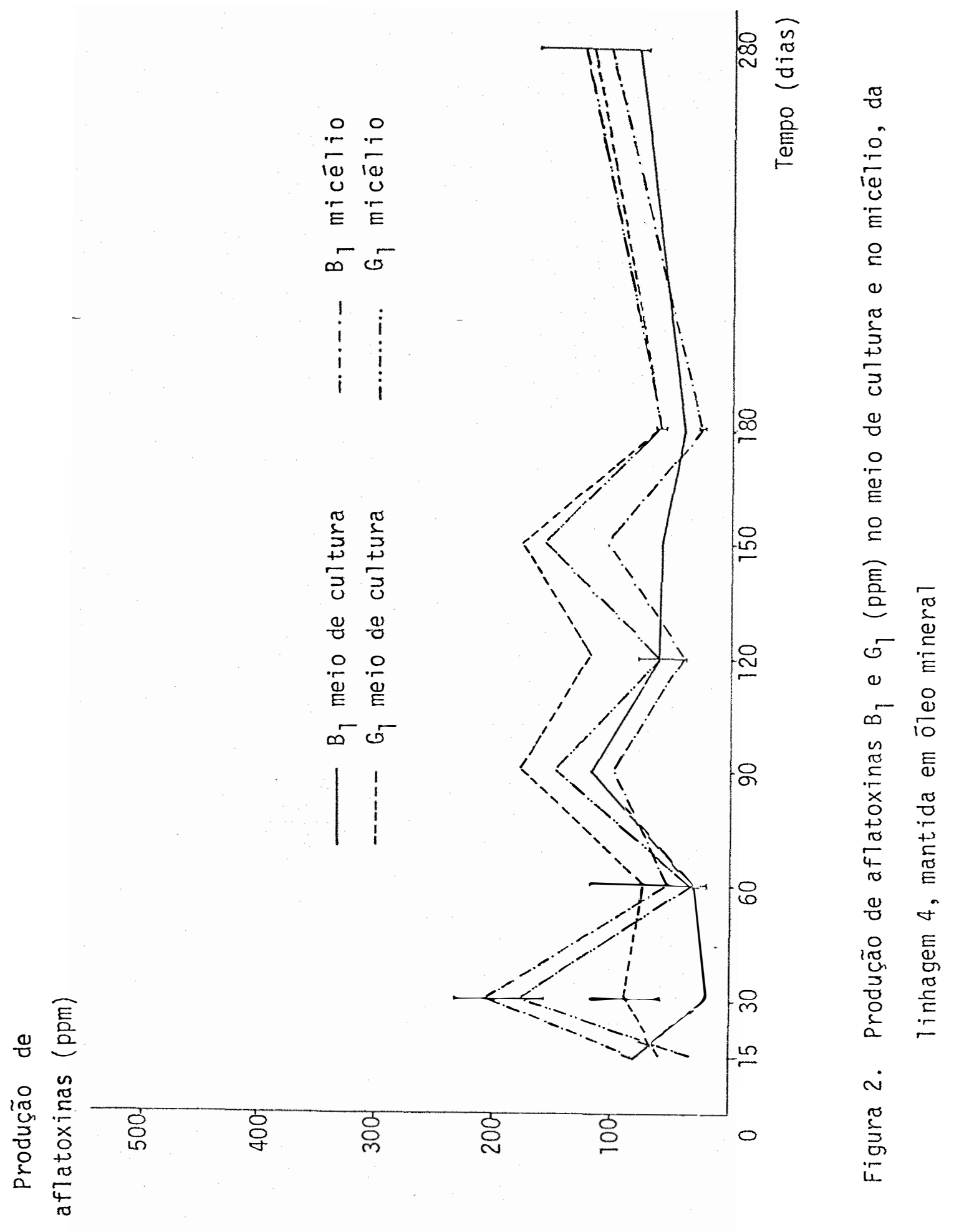




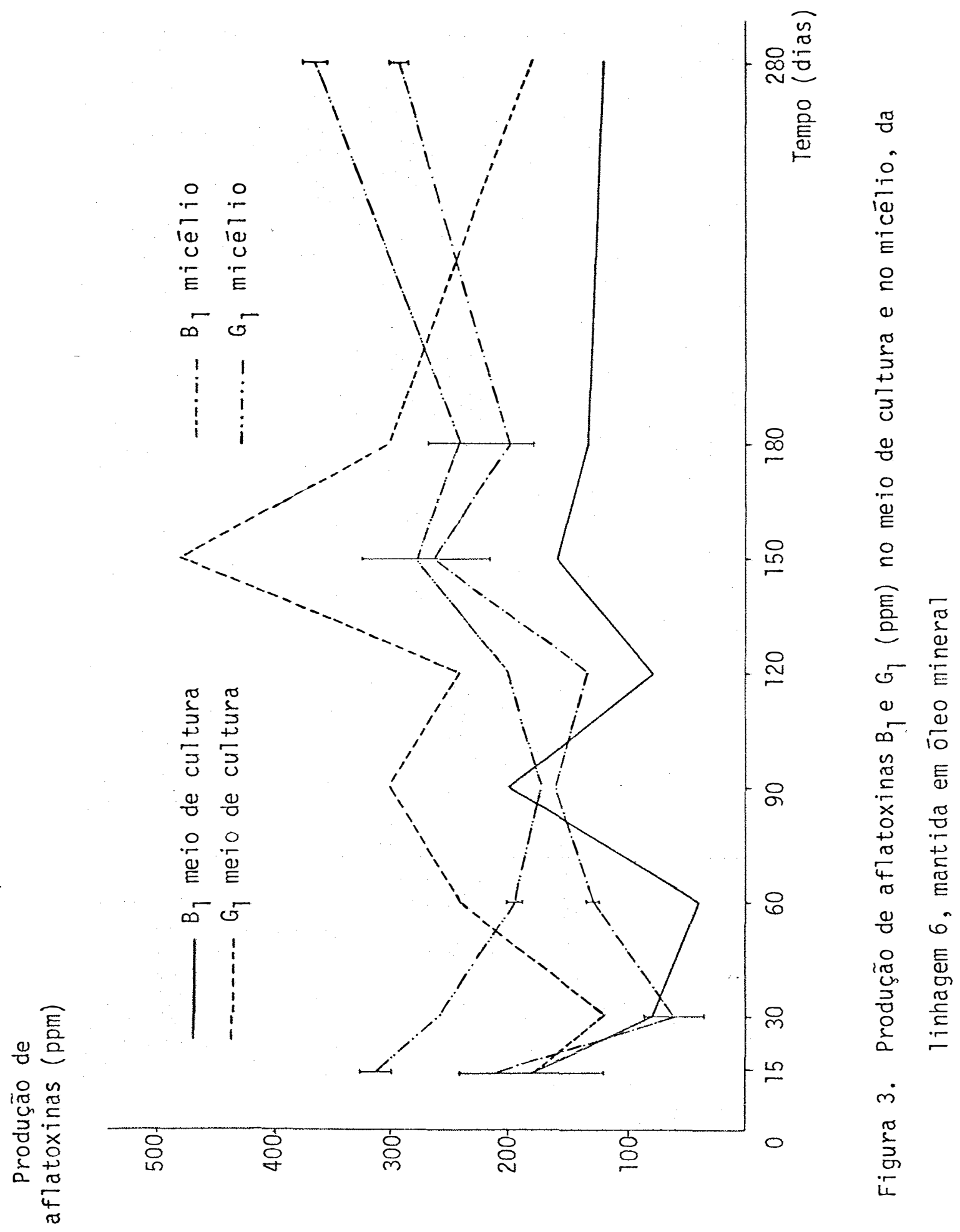


4.3. Produção de Aflatoxinas pelas Linhagens Repicadas. Periodicamente

Em paralelo, com a análise da variabilidade de produção de aflatoxinas em linhagens mantidas no óleo mineral, foi realizada da mesma forma a análise destas linhagens, repicadas periodicamente. As Tabelas 7,8 e 9 apresentam a produção de aflatoxinas das linhagens 2,4 e 6 , respectivamente, repicadas periodicamente, durante o período de 280 dias.

Tabela 7. Produção de aflatoxinas da linhagem 2, repicada periodicamente (Média de duas repetições)

Tempo

(dias)
Produção de aflatoxinas (ppm)

Meio de cultura

$\mathrm{B}_{1} \quad \mathrm{G}_{1}$

Micélio

$B_{1}$

12,0

1,8

0,95

1,05

5,4

0,8

2,7

4,4

4,8

$-$

4,4


Tabela 8. Produção de aflatoxinas da 1 inhagem 4, repicada periodicamente (Média de duas repetições)

\begin{tabular}{|c|c|c|c|c|}
\hline \multirow{2}{*}{$\begin{array}{l}\text { Tempo } \\
\text { (dias) }\end{array}$} & \multicolumn{4}{|c|}{ Produção de aflatoxinas (ppm) } \\
\hline & $\mathrm{B}_{1}$ & $G_{1}$ & $B_{1}$ & $G_{1}$ \\
\hline 15 & 80 & 120 & 77,5 & 68 \\
\hline 30 & 30 & 90 & 44 & 133 \\
\hline 60 & 80 & 180 & 21,7 & 49 \\
\hline 90 & 30 & 45 & 35,5 & 53,3 \\
\hline 120 & 40 & 90 & 36 & 54 \\
\hline 150 & 60 & 90 & 142 & 214 \\
\hline 180 & 80 & 180 & 47,5 & 71,5 \\
\hline 280 & 20 & 120 & 94,7 & 126 \\
\hline
\end{tabular}


Tabela 9. Produção de aflatoxinas da linhagem 6, repicada periodicamente (Média de duas repetições)

\begin{tabular}{|c|c|c|c|c|}
\hline \multirow{3}{*}{$\begin{array}{l}\text { Tempo } \\
\text { (dias) }\end{array}$} & \multicolumn{4}{|c|}{ Produção de aflatoxinas (ppm) } \\
\hline & \multicolumn{2}{|c|}{ Meio de cultura } & \multicolumn{2}{|c|}{ Micélio } \\
\hline & $B_{1}$ & $G_{1}$ & $\mathrm{~B}_{1}$ & $G_{1}$ \\
\hline 15 & 70 & 105 & 128 & 193 \\
\hline 30 & 140 & 210 & 177 & 266 \\
\hline 60 & 80 & 240 & 212 & 318 \\
\hline 90 & 80 & 80 & 152 & 163 \\
\hline 120 & 80 & 157 & 111 & 166 \\
\hline 150 & 120 & 180 & 183 & 235 \\
\hline 180 & 80 & 120 & 54 & 81 \\
\hline 280 & 30 & 90 & 30,7 & 46,2 \\
\hline
\end{tabular}

Estes dados novamente nos mostram que não houve grande uniformidade na produção de aflatoxinas, durante os periodos estudados, mesmo nas linhagens repicadas periodicamente. Cada linhagem continuou produzindo aflatoxinas no meio de cultura e no micēlio, sem perder as características de produção das culturas iniciais. Embora, em algumas épocas, a produção de aflatoxinas tenha diminuido mais de $50 \%$, em outras ēpocas a produção aumentou mais de $100 \%$ quando comparadas às cutturas iniciais. 
Não se pōde notar diferenças entre as culturas mantidas em bleo mineral, com as culturas repicadas periodicamente, com respeito à produção de aflatoxinas. A média foi tomada de duas repetições, mas houve diferenças em algumas repetições, mesmo sendo trabalhadas em condições similares.

Os dados das Tabelas 7,8 e 9 podem ser melhor visualizados nas Figuras 4,5 e 6 , respectivamente.

\subsection{Observação dos Caracteres Morfológicos dos Fungos}

Estas linhagens diferem morfologicamente, na coloração de suas colōnias, produção de esporos, tamanho dos conídios e dos conidiōforos.

Quando elas foram testadas, quanto à produção de esporos, no meio de czapeck modificado e no amendoim autoclavado, as linhagens 2 e 4 produziram esporos abundantemente, tanto no meio de cultura como no amendoim. A linha gem 6 por sua vez, produziu poucos esporos em ambos substratos e houve ocasiões em que seu crescimento foi predominante mente micelial. Contudo, sua produção de aflatoxinas não di minuiu significantemente e não foi notada nénhuma relação en tre produção de aflatoxinas e esporulação, uma vez que a pro dução de aflatoxinas ocorreu tanto na forma micelial, como na forma esporulada. 


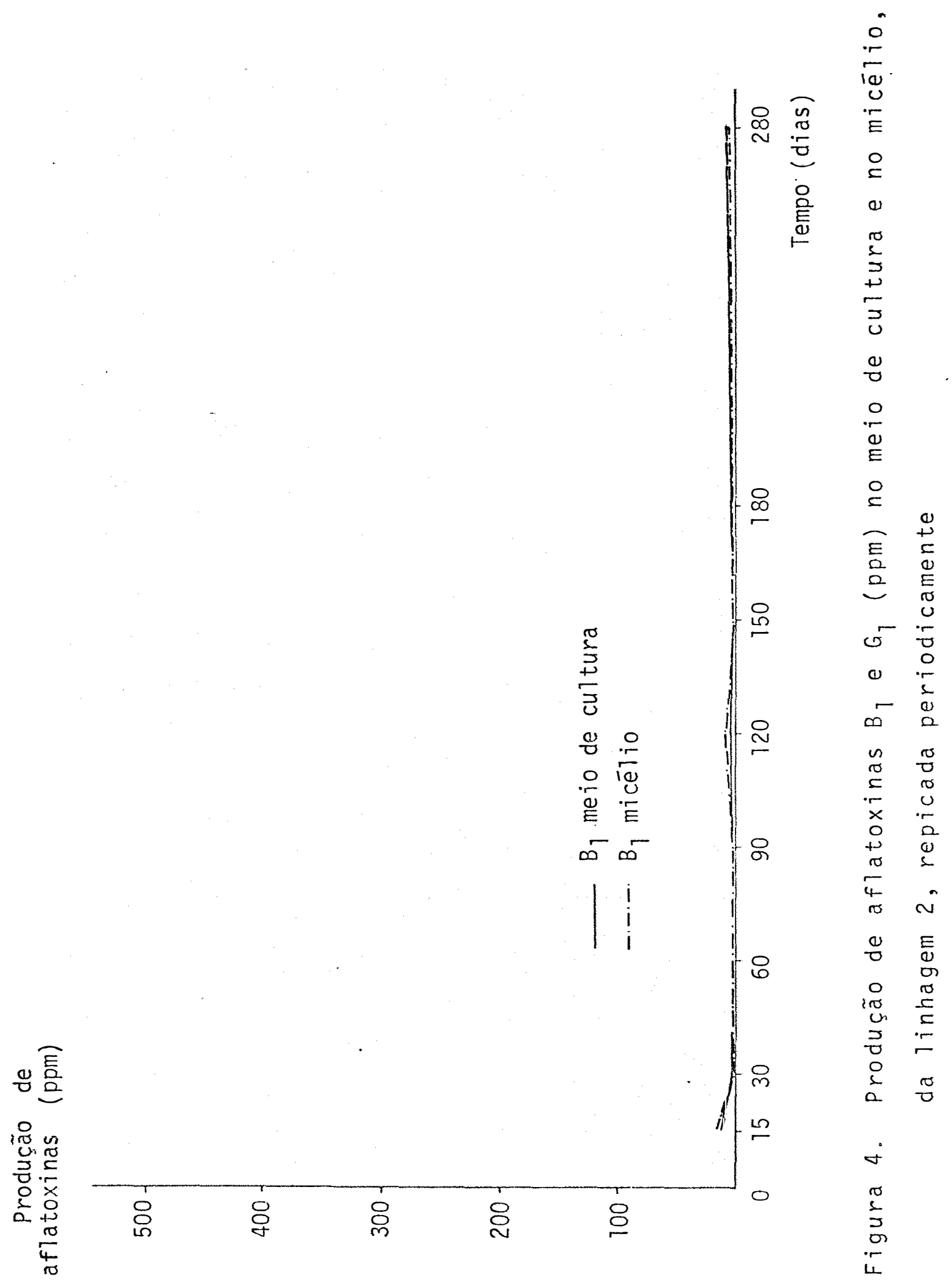




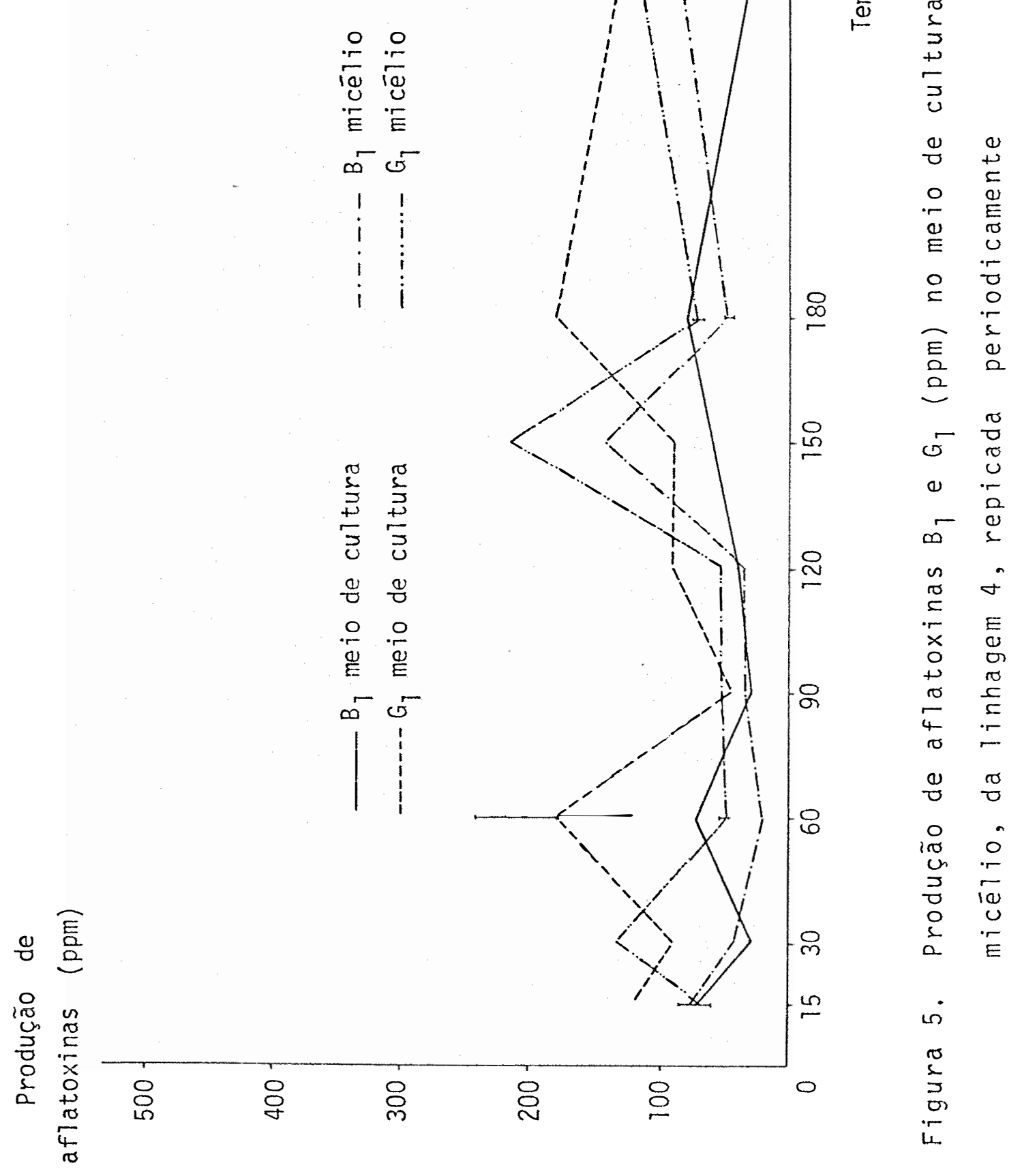




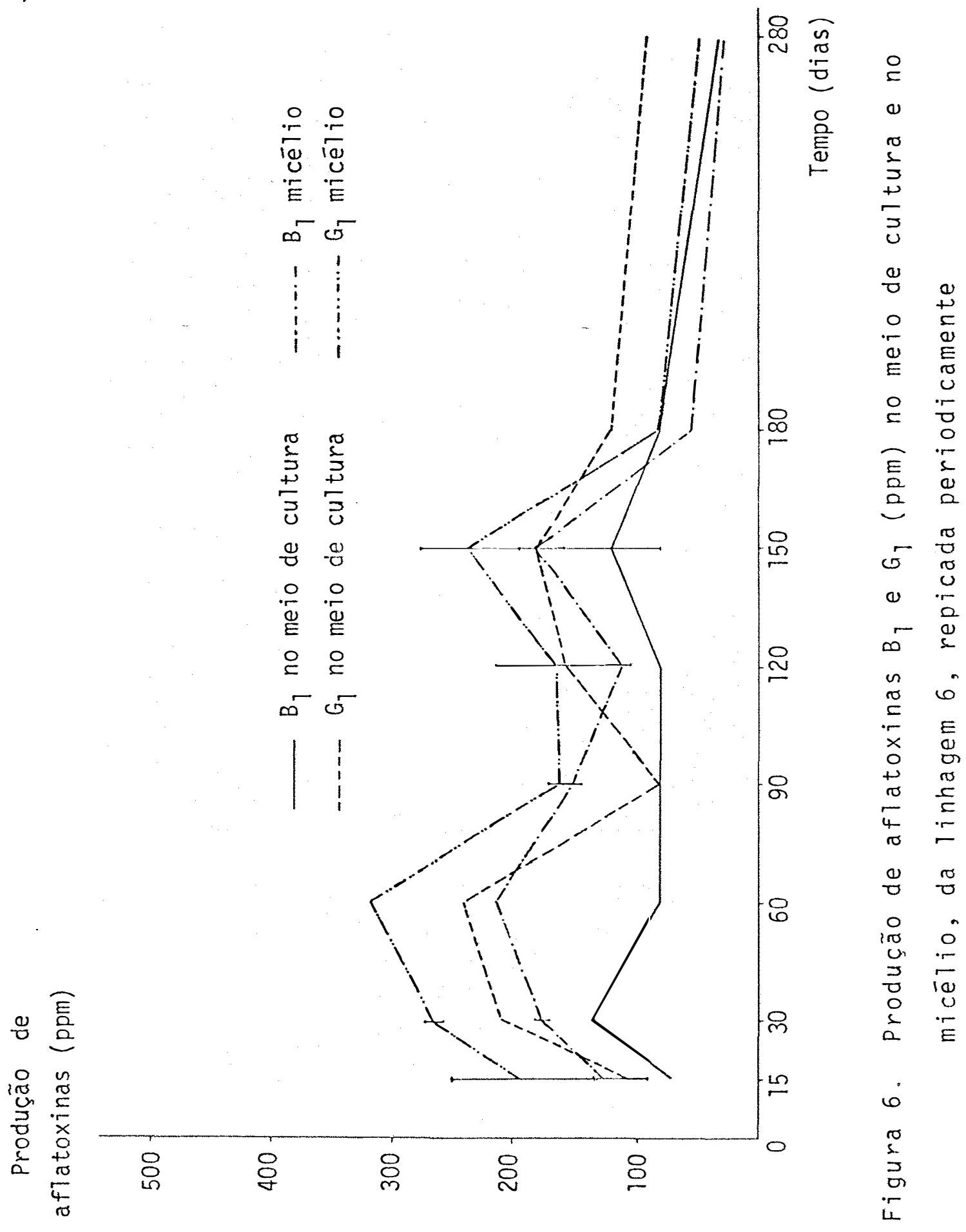


Analisando os fungos microscopicamente, verificou-se que a linhagem 6 apresenta poucos conidióforos, e de tamanho reduzido, enquanto que a linhagem 2 em geral apre sentou o maior nūmero de conidióforos e também de maior tamanho. A linhagem 4 apresentou poucos conidióforos e de tamanho intermediário.

Observou-se, tambēm, em todas as linhagens, uma região de alargamento de hifas com paredes espessas e presença de algumas estruturas globosas. Nessa região quase não se verificou a presença de conidióforos. No presente trabalho o estudo destas estruturas não foi aprofundado. Con tudo, estas observações sugerem a necessidade de um posterior estudo sobre tais caracteres, que poderiam estar relacionados com a produção de aflatoxina nestes fungos. 


\section{DISCUSSÃO}

5.1. Variação na Produção de Aflatoxinas nas Linhagens Mantidas em Óleo Mineral e Repicadas Periodicamente

Ao compararmos os grāficos de produção de aflatoxina, dos fungos mantidos em öleo mineral (Figuras 1 , 2 e 3 ), com os gráficos dos fungos repicados periodicamente (Figuras 4, 5 e 6 ), podemos observar que ambos se comportaram de forma semelhante. A produção de aflatoxinas nas trēs linhagens, durante cada época do experimento, não se manteve uniforme, embora cada linhagem não tenha perdido a caracteristica da cultura original, isto é, a linhagem 2 continuou produzindo pouca aflatoxina, enquanto as outras duas linhagens continuaram produzindo maiores quantidades. De acordo com FENNELL (1960) estas variações ocorrem durante as transferéncias miceliais, de um frasco para outro e quando o inóculo é tomado de àreas envelhecidas, o acúmulo do produto de metabolismo pode exercer influéncia mutagénica. 
Muitos laboratórios têm se preocupado em des cobrir métodos para manter os fungos estocados por longos períodos, contudo a maioria das técnicas têm procurado extender a longevidade das culturas, sem se importar com a ma nutenção das características fisiológicas como: patogenicidade, produção de substãncias de interesses comerciais (antibiōticos, enzimas, etc.) e no nosso caso a produção de aflatoxinas.

Um estudo detalhado sobre os métodos de preservação de fungos, foi fornecido por FENNELL (1960). Nest estudo foi discutido tanto o método de preservação em óleo mineral como o mētodo de repicagem sucessiva, ambos utilizados no presente experimento. O primeiro método atua pela prevenção da desidratação e retardamento tanto da atividade metabólica, como do crescimento por causa da redução do con sumo de oxigènio. A viabilidade da cultura é geralmente aumentada e um grande nümero de fungos têm sido preservados por este método e sobrevivido por longos períodos. Tem sido relatada redução na patogenicidade em culturas mantidas em óleo mineral, apōs dois anos. Além disso, cuidado deve ser tomado, na transferéncia de uma cultura mantida em óleo mineral, para uma subcultura, pois, a variação geralmente ocorre nesta fase. Por outro lado, no método de transferén cias sucessivas a variação è ainda aumentada, pois, hà um 
constante dano cultural ou variação fisiológica em cada período de recrescimento, principalmente se entrar um grau de seleção dentro de cada inōculo durante as repicagens sucessivas.

Neste experimento o fungo mantido em óleo mi neral, foi menos trabalhado que o repicado periodicamente, contudo, a variação ocorreu em ambos. De acordo com MOREAU (1979), a produção de aflatoxina é geralmente proporcional ao peso do micélio formado na cultura, sendo um máximo produzido quando a biomassa atinge o seu valor ótimo e declina rapidamente no momento em que o micélio inicia a sua autólise. Portanto, a variação ocorreu provavelmente devido ao inóculo, que nem sempre produziu a mesma quantidade de micé lio e consequentemente de aflatoxina.

No estudo de DOYLE e MARTH (1978b) também foi verificado que linhagens crescidas sob condições simila res, podem variar na sua habilidade de degradar aflatoxina e isso está diretamente relacionado com a quantidade de toxina produzida. De acordo com estes autores houve uma variabilidade biológica na produção, devido às pequenas diferenças nas condições ambientais.

BOLLER e SCHROEDER (1974) também confirmaram este fato, em seus estudos com conidios estocados, onde a 
produção de aflatoxina $B_{1}$ não foi uniforme. Eles verificaram grande diferença na alta e baixa produção em cada isolado, nas diferentes épocas de seus experimentos. Segundo estes autores, as diferenças na quantidade de aflatoxina detectadas nesta cultura, refletiram provavelmente, as variāveis na preparação do experimento e tais variações poderiam ser causadas por um ou mais destes fatores: 1) a desuniformidade na composição do substrato, uma vez que neste experimento o substrato utilizado foi o arroz; 2) a variação na idade do inōculo; 3) a variação na taxa de crescimen to, de um periodo para outro, devido a causas desconhecidas; 4) as diferenças nas transferēncias dos conidios, pela alça de platina, uma vez que não se pode saber exatamente qual o nümero de conî́dios introduzidos; 5) a seleção dos co nídios nas vārias áreas da colónia, levando a uma variação no nümero dos conídios viāveis transferidos para o outro frasco; e, 6) a quantificação de aflatoxina pelo método visual em cromatografia de camada delgada, que geralmente pode propiciar um erro de aproximadamente $20 \%$, mesmo com analistas experientes.

A variação na produção de aflatoxinas encontrada no presente experimento, nos leva a crer que foi consequéncia de alguns dos fatores citados acima como, por exemplo, a variação na idade dos conídios inoculados, duran te cada fase do experimento. Neste experimento procurou-se 
sempre escolher área de crescimento da colōnia. Contudo, é difícil ter o mesmo número de conídios viāveis em cada inōculo transferido. A técnica de quantificação pelo método visual, também pode ter contribuído com erros. Portanto, a variação na produção de aflatoxinas, por uma linhagem, pa rece ser um problema comum, entre os pesquisadores e, de fa to, é muito dificil manter todas as condições rigidamente controladas.

\subsection{Perda na Capacidade de Produzir Aflatoxinas}

Durante este período de 280 dias, nenhuma $1 \underline{i}$ nhagem perdeu sua capacidade de sintetizar aflatoxina, num meio de cultura sintético. BOLLER e SCHROEDER (1974) também verificaram que mesmo com a degeneração e morte dos conídios estocados durante 21 meses, a produção de aflatoxina nas linhagens estudadas não cessou, embora esta não permanecesse constante.

Por outro lado, TORRES et alii (1980) citam vārios autores que têm investigado a influência de fontes de carboidratos, nitrogênio orgānico e inorgānico, extrato de levedura, vitaminas e certos minerais na sintese de afla toxinas, por espécies de Aspergillus. Segundo os autores citados, as finhagens aflatoxigênicas perdem esta caracterîstica após subculturas sucessivas em meios sintéticos. 
Utilizando o trigo como substrato natural, estes autores, esperavam encontrar um aumento na sintese de aflatoxinas co mo jā foi encontrado em alguns trabalhos. Todavia, ao invés disso, houve degeneração após transferēncias sucessivas, e alguns fungos toxigenicos perderam totalmente a capa cidade de sintese de aflatoxinas.

Figueiredo e PIMENTEL (1975) estudando os mé todos de conservação de fungos, verificaram que os fungos, mantidos em coleções, alteraram-se profundamente com o tempo, deixando de apresentar alguns caracteres da cultura or $\underline{i}$ ginal, ou, o que é mais raro, adquirindo certos caracteres inexistentes naquela. A explicação para isto, segundo estes autores, seria a ocorrência de saltações, mutações e ou tras alterações nucleares que resultam em alterações morfológicas e fisiológicas como: modificação do aspecto ou cor da cultura, perda da capacidade de esporulação, redução ou perda de patogenicidade, perda da capacidade de sintetizar certas substāncias e outras modificações, em geral irreversíveis, comuns em fungos mantidos em vida saprofitica sobre meios nutrientes ricos. Esta colocação poderia explicar os casos ocorridos em que os fungos perderam a capacidade de sintetizar aflatoxinas. Contudo, ao se pensar em mutação, deve-se lembrar que a taxa de mutação é muito baixa e seria difícil ocorrer em todos os casos e portanto, provavelmente, outros mecanismos devem estar envolvidos. 


\subsection{Observação dos Caracteres Morfológicos.}

Ao relacionar alguns caracteres morfológicos dos fungos toxigēnicos, com a produção de toxina, podemos verificar que muitos trabalhos anteriores jā se preocuparam em distinguir isolados toxigènicos e não toxigēnicos, com base nas características morfológicas. Jacquet e Boutibonnes, 1969 (citado por MOREAU, 1979) notaram uma hipertro fia em certas partes do micélio nas linhagens toxigênicas; os esferócitos e a aparēncia anōmala foram considerados como características de clones de produção de aflatoxinas. Além destes autores, outros têm procurado relacionar a presença de esclerócios (MURAKAMI et alii, 1968; TORRES et alii, 1980; WICKLOW e SHOTWELL, 1982); de blastosporo (BHATNAGAR et alii, 1982); e clamidosporo (ABOU-GABAL e FAGERLAND, 1981), com a produção de aflatoxinas.

Por outro lado, MOREAU (1979) chama a atenção, ao associar certos caracteres morfológicos ou químicos entre as linhagens produtoras e não produtoras, ao fato de uma linhagem toxigênica vir a perder sua habilidade de produzir aflatoxina, após subculturas sucessivas em meios sintéticos, ou em alguns casos aumentar sua toxigenicidade por meio de subculturas sucessivas num substrato natural apropriado. 
Atē o momento, nenhuma linhagem toxigēnica foi estudada, relacionardo trocas morfológicas e fisiológicas, durante o tempo de estocagem, com a produção de aflatoxinas. No presente trabalho, as linhagens foram observadas microscopicamente, no inicio e no fim do experimento, não tendo havido um acompanhamento em cada etapa da extração de toxina. Foi detectada uma região de alargamento e espessamento de hifas, com algumas estruturas globosas que poderiam estar associadas aos locais de produção de aflatoxinas, citados pelos autores acima. Portanto, estes fatos sugerem que estudos posteriores, acompanhando a produção de aflatoxinas, juntamente com estudos morfológicos e citológ cos em cada época de anālise, num período mais longo de estocagem, devem ser realizados.

5.4. Produção de Aflatoxinas em Substratos Diferentes.

Pelos estudos realizados até o presente, parece que ainda não hā uniformidade de dados quanto à perda de produção de aflatoxinas, apōs subculturas sucessivas em meio sintético e em substrato natural. Se por um lado alguns autores verificaram aumento na toxigenicidade em fungos mantidos em substrato natural (WICKLOW et alii, 1981), outros, como TORRES et alii (1980), verificaram perda em a gumas linhagens. Portanto, estes fatos novamente sugerem 
que adicionais pesquisas, comparando o comportamento do fun go em substratos naturais e em meios sintéticos são necessários. Provavelmente esta perda, ou aumento de toxigenicidade, está relacionada com a resposta do fungo aos fatores ambientais.

De acordo com MOREAU (1979), o fungo A. Glavus é um fungo encontrado no solo, geralmente na matéria orgānica e em sementes, especialmente as oleaginosas. Ele geralmente é acompanhado por numerosos outros fungos, e o seu crescimento pode, às vezes, ser inibido por fungos como Aspergillus niger, Rhizoctonia solani ou espécies de Penicillium, como também ele pode retardar o crescimento de espécies de sclerotium bataticola. As propriedades toxigênicas de uma cultura podem ser mascaradas, se os metabólitos tóxicos são subsequentemente transformados em derivados não tóxicos por outros microrganismos.

Na natureza ocorre uma interação microbiológica, onde a produção de toxina dá uma certa vantagem seletiva ao organismo produtor. Enquanto quase todas as linhagens de A. parasiticus são toxigênicas, em A. Glavus nem to das as linhagens produzem aflatoxinas. Em ambas as espécies a produção está relacionada com as condições ambientais e segundo Schroeder e Anshworth, 1966 (citado por MOREAU, 1979), a produção de aflatoxina é o resultado da 
interação do genótipo de uma linhagem e o ambiente em que ela está crescendo.

Portanto, o que levaria uma linhagem toxigênica que está sendo cultivada em laboratório, sobre um meio sintético rico, perder sua toxigenicidade, talvez esteja re lacionada ao fato de se adaptar às condições saprofiticas de laboratório e o mesmo poderia acontecer num substrato na tural livre de outros microrganismos. O aumento na toxigenicidade no substrato natural, observado por alguns autores, provavelmente ocorre só no inĩcio.

0 meio de Czapeck utilizado no presente expe rimento è pobre em nutrientes, isto é, o fungo necessita sintetizar substancias mais complexas, a partir de fontes simples. Provavelmente, o fungo cultivado em meios sintéticos ricos, perde sua capacidade de produzir aflatoxinas com maior facilidade que o fungo cultivado em meios mais po bres, uma vez que naquele meio o fungo encontra a substāncia pronta sem precisar seguir algumas vias metabölicas para sua sintese. Desta forma um estudo comparando o comportamento do fungo toxigēnico num meio sintético rico, com um meio sintético pobre, além de um substrato natural poderia esclarecer estas suposições. 


\subsection{Aflatoxinas e Micovírus}

No presente trabalho procuramos considerar algumas das hipóteses que tem sido levantadas pelos pesquisadores, com relação ao mecanismo de produção de aflatoxinas. Uma destas hipōteses, que vem sendo estudadas, è a presença das VLP ("virus-like particles") com a produção de aflatoxinas.

Para se saber, seguramente, se as VLP estão ou não relacionadas com a produção de aflatoxinas, é preciso analisar um número significante de linhagens produtoras e não produtoras, juntamente com a presença ou não de micovîrus. Além disso, é preciso conhecer melhor o papel das VLP nos fungos; a maioria delas em condições normais, pare cem ser latentes. Embora as VLP sejam transmitidas por esporos, faltam ainda estudos para verificar se são herdadas como um fator nuclear ou citoplasmático (WOOD et alii, 1974).

De acordo com HOLLINGS (1978) ainda não hā um padrão geral uniforme, com relação à presença de infecção viral e micotoxinas, há somente alguns relatos comparando isolados infectados por vírus e livres de vírus, que podem bem diferir geneticamente em certos caracteres metabólicos. 


\subsection{Aflatoxinas: um Metabólito Secundário}

A esta altura podemos relacionar as aflatoxi nas como um metabōlito secundārio do fungo A. flavus. De acordo com WANG et alii (1979) e a maioriados autores, metabōlitos secundários são substāncias sintetizadas por certos microrganismos, geralmente no final do ciclo de crescimento, e embora não necessārios ao seu crescimento, estes metabólitos podem ter valores de sobrevivencia para o organismo produtor. No caso das aflatoxinas, elas podem ser de tectadas 48 horas após a germinação do esporo, e o seu ciclo celular è de 24 horas.

Não conhecemos ainda o verdadeiro significado do metabolismo secundário nos organismos. Por que os microrganismos sintetizam os metabōlitos secundários? E evi dente que, a menos que o microrganismo possua a informação codificada no seu genoma, para a sīntese de metabólitos secundários, ele é incapaz de sintetizá-los, e a expressão desta informação é regulada por uma variedade de fatores am bientais.

ROSE (1979) revisando vārios autores sobre a razão da síntese de metabōlitos secundários, tomou, como ex plicação mais coerente, o fato de que os organismos que entram na fase estacionāria do crescimento e são incapazes de impedir a sintese de intermediários de baixo peso molecular, 
podem desviar estes intermediārios dentro da sīntese de uma variedade de metabólitos secundārios. Nos organismos que não sintetizam os metabólitos secundārios, assume-se que es tes possuem mecanismos que impedem a sintese de compostos de baixo peso molecular, que durante o crescimento são conduzidos à sintese de seus constituintes celulares.

Schroeder e Verrett, 1969 (citado por SCHMIDT et alii, 1977) sugeriram que linhagens produtoras de aflatoxinas acumulam toxinas como produtos finais, enquanto que as não produtoras podem metabolizar a toxina em. proporções iguais à medida em que ela é sintetizada.

Neste trabalho procuramos contribuir para um melhor entendimento dos fatores envolvidos na produção de aflatoxinas, durante o período de estocagem, contudo não sa bemos se as linhagens que conhecemos como não produtoras de aflatoxinas (dentro do grupo A. Glavus)realmente não produzem porque não tēm a informação genētica em seu genoma, ou porque ela perdeu esta capacidade de produzir devido a algum efeito ambiental natural. Sabemos que as linhagens aflatoxigēnicas, mantidas em laboratório, com o tempo podem perder esta característica, mas não sabemos se o que aconte ce num laboratório, pode acontecer num ambiente natural. 


\section{CONCLUSOOES}

Do presente trabalho, as seguintes conclusões podem ser tiradas:

1) A produção de aflatoxinas, numa linhagem, pode variar e esta variação provavelmente estā relacionada com as condições do experimento como: nümero de conídios viāveis, técnicas de transferéncia do inóculo, idade dos co nídios, técnicas de quantificação de aflatoxinas e outros fatores que geralmente são difíceis de serem controlados.

2) A produção de aflatoxinas nestes fungos, não cessou durante o período de 280 dias, tanto nos que foram mantidos em óleo mineral, como nos repicados periodicamente.

3) Não houve diferença no comportamento de produção de aflatoxinas, no fungo mantido em óleo mineral, com o fungo repicado periodicamente, durante este periodo. 
4) Caracteres morfológicos, observados microscopicamente, podem estar relacionados às āreas de adaptação de produção de aflatoxinas. 


\section{LITERATURA CITADA}

ABOU-GABAL, M. e J.FAGERLAND. 1981. Ultrastructure of the chlamydospode growth phase of Aspergillus parasiticus associated with higher production of aflatoxins. Mykosen, $24: 307-311$.

BENNETT, J.W., C.H.VINNETT E W.R.GOYNES Jr. 1980. Aspects of parasexual analysis in Aspergillus parasiticus. Canadian Journal Microbiology, 26:706-713.

BHATNAGAR, R.K., S.AHMAD, K.G.MUKERJI e T. A. VENKITASUBRAMANIAN. 1982. Role of blastospores in protecting Aspergillus parasiticus NRRL 3240 from high levels of aflatoxins. Applied and Environmental Microbiology, $\quad 44: 579-582$. 
BOLLER, R.A. e H.W.SCHROEDER. 1974. Production of aflatoxin by cultures derived from conidiastored in the laboratory. Mycologia, 66:61-66.

CHRISTENSEN, C.M. 1975. Some reflections on micotoxicosis (an introduction). Int.J.Environ. Stud., 8:153-157.

CODNER, R.C., K.SARGEANT e R.YE0. 1963. Production of aflatoxin by the culture of strains of Aspergillus blavusoryzae on sterilized peanuts. Biotechnology and Bioengineering 5:185-192.

COOMES, T.J. e A.J.FEUELL. 1965. Recommended procedures for the detection and estimation of aflatoxin $B_{1}$ in groundnuts and groundnut materials. Tropical Products Institute, Report G 13, Londres.

DAVIS, N.D., U.L.DIENER e D.W.ELDRIDGE. 1966. Production of aflatoxins $B_{1}$ and $G_{1}$ by Aspergillus blavus in semisynihetic medium. Applied Microbiology, 14:378-380.

DIENER, U.L. e N.D.DAVIS. 1969. Aflatoxin formation by Aspergillus blavus. In: L.A.GOLDBLATT, Aflatoxin Cap.IIAcademic Press, New York, London, 472 p. 
DONKERSLOOT, J.A., R.I.MATELES E S.S.YANG. 1972. Isolation of averufin from a mutant of Aspergillus parasiticus impaired in aflatoxin biosynthesis. Biochemical and Biophysical Research Communications, 47:1051-1055.

DOYLE, M.P. e E.H.MARTH. 1978a. Aflatoxin is degraded by micelia from toxigenic and nontoxigenic strains of Aspergilli grown on different substrates. Mycopathologia, $63: 145-153$.

DOYLE, M.P. e E.H.MARTH. 1978b. Aflatoxin is degraded by fragmented and intact mycelia of Aspergillus parasiticus grown 5 to 18 days with and without agitation. Journal of Food Protection, 41: 549-555.

DOYLE, M.P. e E.H.MARTH. '1978c. Aflatoxin is degraded by heated and unheated mycelia, filtrades of homogenized mycelia and filtrades of broth cultures of Aspergillus parasiticus. Mycopathologia, 64: 59-62.

DOYLE, M.P. e E.H.MARTH. 1979. Peroxidase activity in mycelia of Aspergillus parasiticus that degrade aflatoxin. European Journal of Applied Microbiology and Biotechnology, $7: 211-217$ 
ELLIS, J.J. 1969. An orange-yellow mutant of Aspergillus parasiticus produces aflatoxin. Mycologia, 61:651-653.

FENNELL, D.I. 1960. Conservation of fungous cultures. Botanical Review, 26:79-141.

Figueiredo, M.B. e C.P.V.Pimentel. 1975. Métodos utilizados para conservação de fungos na Micoteca da Seção de Micologia Fitopatológica do Instituto Biológico. Summa Phytopathologica, 1:299-302.

FONSECA, H., A.MARTINELLI FILHO, H.DEL NERY e E.RONCATTO. 1974. Espēcies de Aspergillus produtoras de aflatoxina, na Região Araraquarense, SP. Anais da Escola Superior de Agricurtura "Luiz de Queiroz", 31:519-536.

GUSSACK, G., J.W.BENNETT, S.CAVALIER e L.YATSU. 1977.

Evidence for the parasexual cycle in a strain of Aspergillus blavus containing virus-like particles. Mycopathologia, 61:159-165.

HESSELTINE, C.W., O.L. SHOTWELL, J.J.ELLIS E R.D. STUBBLEFIELD. 1966. Aflatoxin formation by Aspergillus blavus. Bacteriological Reviews, 30:795-805. 
HOLLINGS, M. 1978. Mycoviruses: viruses that infect fungi. Advances Virus Research, 22:1-53.

LEAICH, L.L. e K.E.PAPA. 1974. Aflatoxins in mutants of Aspergillus blavus. Mycopathologia et Mycologia Applicata, $52: 223-229$.

LEAICH, L.L. e K.E.PAPA. 1975. Identification of diploids of Aspergillus flavus by nuclear condition of conidia. Mycologia, 67:674-678.

LEE, L.S., J.W.BENNETT, L.A.GOLDBLATT e R.E.LUNDIN. 1971. Norsolorinic acid from a mutant strain of Aspergillus parasiticus. Journal of the American oil Chemists' Society, $48: 93-94$.

LIN, M.T. 1980. Biologia dos fungos toxigênicos. Anais do Encontro Nacional de Micotoxinas: problemas e solucões. p. $71-22$.

LIN, Y.C., J.C.AYRES E P.E.KOEHLER. 1980. Influence of temperature cycling on the production of aflatoxins $B_{7}$ and $G_{1}$ by Aspergillus parasiticus. Applied and Environmental Microbiology, 40: 333-336. 
MESSIAS, C.L., A.MARTINELLI FILHO, H.FONSECA E J.L.AZEVEDO. 1976. Mutantes em linhagens de Aspergillus flavus, Link produtoras de aflatoxina. Ciência e Cultura, 28 (Suplemento) $23-4.1 .7 . p .253$.

MESSIAS, C.L. 1977. Parassexualidade e produção de aflatoxina em Aspergillus flavus, Link. Piracicaba, ESALQ/USP, 75 p. (Dissertação de Mestrado).

MIROCHA, C.J., S.V.PATHRE e C.M.CHRISTENSEN. 1979. Micotoxins. In: A.H.ROSE, Economic microbiology, vol. III. Secondary products of metabolism. Academic Press, London, New York, San Francisco. 595 p.

MOREAU, C. 1979. Moulds, Toxins \& Food. John Wiley \& Sons Ltd. 477 p.

MURAKAMI, H., H.SAGAWA e S.TAKASE. 1968. Non-productivity of aflatoxin by japanese industrial strain of the Aspergillus. II Common characteristics of the aflatoxinproducing strains. The Journal General Applied Microbiology, $14: 251-262$.

NORTHOLT, M.D., H.P. van EGMOND e W.E. PAULSCH. 1977. Differences between Aspergillus flavus strains in growth and aflatoxin $B_{1}$ production in relation to water activity and temperature. Journal of Food Protection, 40: 778-731. 
PAPA, K.E. 1973. The parasexual cycle in Aspergillus flavus. Mycologia, 65:1201-1205.

PAPA, K.E. 1976. Linkage groups in Aspergillus blavus. Mycologia, 68:159-165.

PAPA, K.E. 1977. Genetics of aflatoxin production in Aspergillus blavus: Iinkage between a gene for a high $B_{2}: B_{1}$ ratio and the histidine locus on linkage group VIII. Mycologia, 69:1185-1190.

PAPA, K.E. 1978. The parasexual cycle in Aspergillus parasiticus. Mycologia, 70:766-773.

PAPA, K.E. 1979. Genetics of Aspergillus flavus: complementation and mapping of aflatoxin mutants. Genetic Research, 34:1-9.

PAPA, K.E. 1982. Norsolorinic acid mutant of Aspergillus blavus. Journal of General Microbiology, 128:1345-1348.

PONTECORVO, G. e J.A.ROPER. 1952. Genetics analys is without sexual reproduction by means of polyploidy in Aspergillus nidulans. Proceding Journal Genetics Microbiology, 6 : Abstract. 
PONTECORVO, G., J.A.ROPER, L.M.HEMMONS, K.D.MACDONALD e A. W.BUFTON. 1953. The genetics of Aspergillus nidulans. Advances in Genetics, 5:141-238.

RAO, V.M., K.K.MAGGON e T.A.VENKITASUBRAMANIAN. 1980. 0xidases in Aspergillus parasiticus in relation to aflatoxin biosynthesis. Toxicon, 18:279-283.

RAPER, K.B. e D.I.FENNELL. 1965. The genus Aspergillus. The Williams \& Wilkins Company Baltimore.

REDDY, T.V., L.VISWANATHAN E T.A.VENKITASUBRAMANIAN. 1979. Factors affecting aflatoxin production by Aspergillus parasiticus in a chemically defined medium. Journal of General Microbiology, 144: 409-413.

REIB, J. 1982. Development of Aspergillus parasiticus and formation of aflatoxin $B_{l}$ under the influence of conidiogenesis affecting compounds. Archives of Microbiology, 133:236-238.

ROSE, A.H. 1979. Economic microbiology, vol.III. Secondary products of metabolism. Academic Press, London, New York, San Francisco. 595 p. 
SCHMIDT, A.L., C.R.CURTIS E G.A.BEAN. 1977. Eletrophoretic comparisons of mycelial enzymes from aflatoxin-producing and non-producing strains of Aspergillus flavus and Aspergillus parasiticus. Canadian Journal Microbiology, $23: 60-67$.

SCHROEDER, H.W. e W.W.CARLTON. 1973. Accumulation of only aflatoxin $B_{2}$ by a strain of Aspergillus blavus. Applied Microbiology, 25:146-148.

SCOTT, P.M., J.W.LAWRENCE e W.van WALBEEK. 1970. Detection of mycotoxins by thin-layer chromatography: application to screening of fungal extracts. Applied Microbiology, 20: $839-842$.

SINGH, R. e D.P.H.HSIEH. 1977. Aflatoxin biosynthetic pathway: elucidation by using blocked mutants of Aspergillus parasiticus. Archives of Biochemistry and Biophysics, $178: 285-292$.

TORRES, J., J.guARro, G.SUAREZ, N.SUÑE, M.A.CAlVo e C. RAMIREZ. 1980. Morphological changes in strains of Aspergillus blavus Link ex Fries and Aspergillus parasiticus Speare related with aflatoxin production. Mycopathologia, $72: 171-174$. 
MANG, D.I.C., C.L.COONEY, A.L.DEMAIN, P.DUNNILL, A.E. HUMPHREY e M.D.LILLY. 1979. Fermentation and enzyme technology. John Wiley \& Sons, Inc. $374 \mathrm{p}$.

WICKLOW, D.T., O.L.SHOTWELL, G.L.ADAMS. 1981. Use of aflatoxin-producing ability medium to distinguish aflatoxin-producing strains of Aspergillus blavus. Applied and Environmental Microbiology, 41:697-699.

WICKLOW, D.T. E O.L.SHOTWELL. 3982. Intrafungal distribution of aflatoxin among conidia and sclerotia of Aspergillus flavus and Aspergillus parasiticus. Canadian Journal Microbiology, $29: 1-5$.

WOOD, H.A., R.F.BOZARTH, J.ADLER E D.W.MACKENZYE. 1974. Proteinaceous virus-like particles from an isolate of Aspergillus flavus. Journal of Virology, 13: 532-534. 